\title{
Spreading the Misery? Sources of Bankruptcy Spillover in the Supply Chain
}

\author{
Madhuparna Kolay, Michael Lemmon, and Elizabeth Tashjian*
}

\begin{abstract}
We document that suppliers to purely financially distressed companies that are highly likely to reorganize in bankruptcy incur little or no spillover costs. In contrast, suppliers to economically distressed firms experience large losses in market value that are linked to proxies for the cost of replacing the bankrupt customers. Suppliers experience increased selling, general, and administrative (SG\&A) expenses and lower margins in the year following the bankruptcy of their trading partners, which we link to proxies for partner replacement costs. Suppliers continue to extend trade credit to firms that are healthier and in situations where the cost of replacing the partner is higher.
\end{abstract}

\section{Introduction}

On March 19, 2009, the U.S. Department of the Treasury announced a program to provide up to $\$ 5$ billion to "stabilize" suppliers to the troubled domestic automobile industry. ${ }^{1}$ Implicit in Treasury Secretary Timothy Geithner's justification for the program is the belief that distress at one firm can "spill over" and transmit real costs along the supply chain. We study the effect of a firm's distress on its major suppliers and customers and provide new insights into the sources of spillover. We find that spillover varies considerably among suppliers and customers of distressed firms. For example, we use a measure of the degree of economic, versus financial, distress to estimate an ex ante probability that a firm will survive bankruptcy and find that suppliers to firms that are highly likely to

\footnotetext{
*Kolay, kolay@up.edu, Pamplin School of Business Administration, University of Portland; Lemmon, finmll@business.utah.edu, Tashjian, elizabeth.tashjian@utah.edu, Eccles School of Business, University of Utah. We thank Hank Bessembinder, Jarrad Harford (the editor), Uri Loewenstein, Yung-Yu Ma, and seminar participants at the University of Portland, University of San Francisco, University of Utah, Virginia Tech, and the 2013 American Finance Association (AFA) meeting for helpful comments and Lynn LoPucki's Bankruptcy Research Database for providing a list of bankruptcies (http://lopucki.law.ucla.edu/).

1،"The Supplier Support Program will help stabilize a critical component of the American auto industry during the difficult period of restructuring the [sic] lies ahead," said Treasury Secretary Geithner (http://www.treasury.gov/press-center/press-releases/pages/tg64.aspx).
} 
reorganize in bankruptcy incur little or no spillover costs. In contrast, suppliers to firms that are unlikely to emerge from Chapter 11 as standalone firms experience large losses in market value. Spillover is also affected by other proxies for the cost of replacing a failed partner, including supplier industry concentration and research and development $(\mathrm{R} \& \mathrm{D})$ intensity. We employ a new methodology to identify an announcement date for measuring spillover and find spillover effects for customers of distressed firms and cross-sectional determinants of both supplier and customer spillover that were undetected in prior work. We find strong support for the hypothesis that the cost of replacing a distressed partner is an important determinant of spillover. We explore changes in trade-credit behavior by suppliers prior to the bankruptcy of their trading partners and find that suppliers are more likely to extend additional credit when the probability that their distressed partners will survive is high. Finally, we extend current work by following the financial performance of suppliers after their trading partners file for bankruptcy and find that suppliers experience a transient decrease in profit margins and an increase in selling, general, and administrative (SG\&A) expenses, and we link these changes to the ex ante probability that the distressed firm will survive and other proxies for the cost of replacing a failed partner. Taken together, our results provide insight into the specific circumstances under which distress can transmit costs along the supply chain.

A number of authors, including Lang and Stulz (1992), Ferris, Jayaraman, and Makhija (1997), Hertzel, Li, Officer, and Rodgers (2008), Jorion and Zhang (2007), (2009), and Helwege and Zhang (2016), have documented "spillover effects" of distress, where bankruptcy at a given firm is associated with negative equity returns to that firm's rivals, suppliers, or creditors. Our paper investigates these spillover effects from a fresh perspective. In particular, we assess the extent to which spillover effects arise through an information channel, where distress at a given firm reveals negative information about preexisting issues at other firms, versus the alternative hypothesis that these effects arise because distress at a given firm causes problems at other firms.

Earlier authors have suggested that distressed firms are "contagious" and that distress can affect the economic health of a distressed firm's rivals, its suppliers, and its creditors. The negative returns documented in the literature could arise from several sources. A firm's announcement that it is in distress may release information about the state of the bankrupt firm's industry, as well as the industries of its suppliers or its customers (Lang and Stulz (1992), Jorion and Zhang (2007), and Helwege and Zhang (2016)). Payment defaults, for example, on trade credit, may lead to negative returns to creditors of distressed firms (Jorion and Zhang (2009), Helwege and Zhang (2016)). Several papers relate spillover from distress to the effect of eliminating a distressed firm on its industry rivals or on the industries of its suppliers and customers. For example, in a concentrated industry, removing a distressed firm could have a positive effect on its rivals or a negative effect on its suppliers (Lang and Stulz (1992), Hertzel et al. (2008)). The existing work, however, has not clearly established whether spillover effects impose real social costs on other firms.

We study major suppliers to and customers of firms that ultimately file for Chapter 11 bankruptcy. Bankruptcy filings seldom come as a complete surprise. 
We develop an ordered list of key information that would suggest to the market that a firm is in distress or might file for bankruptcy and examine information releases in the year prior to the Chapter 11 filing. We define the first date on which information from our list is released during the prebankruptcy year as our "distress announcement date." We measure spillover as the abnormal return to suppliers or to customers around the distress announcement date. Suppliers to distressed firms have average cumulative abnormal returns of $-7.3 \%$ on the 5 days surrounding the distress announcement date, and customers of distressed firms have cumulative abnormal returns of $-1.4 \%$, both statistically significant at the $1 \%$ level.

We classify potential sources of spillover effects along the supply chain into three categories: information, credit loss, and the cost of replacing a failed trading partner. We capture information effects with the industry-abnormal returns associated with the distressed firm's announcement. We measure credit-loss spillover as the potential loss to suppliers from trade credit extended to a distressed partner. We define partner replacement cost as the anticipated added cost or reduced profit which a supplier or customer would incur to replace a distressed partner. Partner replacement costs might include search costs to locate a new trading partner, retooling costs, lost profits arising from a lag in replacing a partner, or lower margins if a replacement partner offers less favorable terms. We use proxies for these sources of spillover and test whether these proxies explain the abnormal returns to suppliers or customers in the cross section.

Firms become distressed for a wide variety of reasons. Some firms are financially distressed (i.e., are economically viable but have excessive leverage), whereas other firms are economically distressed and have fundamental problems with their business models that threaten their existence even in the absence of debt (Lemmon, Ma, and Tashjian (2009)). Lemmon et al. show that financially distressed firms that file for Chapter 11 are relatively likely to emerge from Chapter 11 as standalone firms and experience virtually no decrease in scale (measured by total assets) during bankruptcy. In contrast, economically distressed firms are considerably less likely to emerge from Chapter 11 , and if they do, Lemmon et al. find that they shed about half their assets. We follow Lemmon et al. and use the degree to which a firm is economically or financially distressed, along with several other variables, to compute an ex ante probability that a distressed firm will emerge from bankruptcy as a standalone firm.

If partner replacement costs are an important determinant of spillover effects, we conjecture that the higher the probability that a distressed firm will emerge from bankruptcy, the lower the spillover costs should be. Consistent with this reasoning, we find that suppliers to firms that are very likely to emerge from bankruptcy experience few or no ill effects from the distress of their partners, whereas suppliers to firms with a relatively low likelihood of survival have abnormal returns of $-19 \%$ around our distress announcement date. For customers of distressed firms, however, the abnormal return varies little as a function of the likelihood of emergence on their announcement period returns. A customer of a distressed firm may have to pay more for inputs if its distressed partner fails, but a customer of a distressed firm does not face the same risk of losing the market for its goods and services that a supplier to a distressed firm does. Our results suggest 
that proxies for increased costs are important in determining the announcement abnormal returns for customers.

We also find that proxies for other factors that influence replacement costs explain spillover effects in the cross section. Specifically, the more reliant the supplier is on the filing firm, the higher the R\&D intensity, and the more concentrated the supplier's industry, the more negative the abnormal return. Customers of filing firms experience more negative abnormal returns the more reliant they are on their distressed partners and the greater their R\&D intensity. We find that customers of distressed firms appear to learn new information about future prospects of the customers' industries from the news of the distress of their partners, but suppliers to distressed firms do not show signs of information effects. Our proxies for expected trade-credit losses are only marginally significant in explaining the cross section of supplier announcement returns.

Although earlier work has documented spillover effects prior to or at a bankruptcy filing, if the abnormal returns reflect expected changes in revenue or cost, those changes ought to be reflected in the affected firm's actual financial performance following its distressed partner's bankruptcy filing. Therefore, we study suppliers' financial performance after their trading partners file for Chapter 11 and find reduced profit margins and increased SG\&A costs relative to a matched sample of firms. These changes are explained in the cross section by the pre-filing probability that the firm will emerge and by industry concentration. The increase in SG\&A costs and decrease in margins appear to be transitory, consistent with our conjecture that spillover reflects the cost of replacing a distressed partner rather than a permanent reduction in the supplier's profits.

Finally, we examine changes in trade-credit policy and find that suppliers are more likely to increase trade credit prior to the bankruptcy of their distressed partners if the likelihood of survival of their trading partners is high and the cost of replacing the partners is likely to be high. Collectively, these results imply that a firm's bankruptcy can transmit real costs along the supply chain but that these costs vary from substantial to negligible depending on whether a firm is economically or financially distressed, the specificity of the products, and the competitive structure of the markets in which the firms operate.

Our results suggest that several provisions of Chapter 11 are important in limiting spillover costs. Chapter 11 facilitates the reorganization of a purely financially distressed firm with substantial reductions in liabilities while preserving the asset base and basic business model of the firm, leading to little or no spillover cost to suppliers. In addition, our findings suggest that Chapter 11's preferential treatment of trade creditors appears to reduce the credit risk to suppliers of bankrupt firms.

Our work contributes to the literature in a number of areas. Although prior authors have documented information effects (Lang and Stulz (1992), Hertzel et al. (2008)), credit costs (Jorion and Zhang (2009)), and benefits to rivals of bankrupt firms (Lang and Stulz (1992), Jorion and Zhang (2007)), by considering information costs, credit costs, and replacement costs in a unified framework, we believe that we are the first to show clearly that bankruptcy can impose substantial costs on some firms. 
Our work is most closely related to that of Hertzel et al. (2008), who also examine spillover along the supply chain. We follow Hertzel et al. and identify firms in the supply chain by using Compustat's segment data and capture spillover as abnormal returns around a pre-filing event date. However, Hertzel et al. use an event date based on the largest loss in market capitalization in the year prior to the bankruptcy filing. We use a date on which information is released to the market and find stronger spillover effects for suppliers, establish spillover effects for customers, and find cross-sectional determinants of spillover effects that are not apparent in the work of Hertzel et al., who report that "[o]verall, our empirical analyses ... show little evidence of predictable cross-sectional variation in ... abnormal returns to customers and suppliers" (p. 385). By measuring the impact of spillover more accurately, we obtain statistically significant determinants in our cross-sectional analysis that allow us to identify key sources of contagion. This paper differs in other dimensions, too. Hertzel et al. focus on the information channel as a source of spillover and explore spillover in the supplier's industry. Although we control for the information channel, our empirical analysis centers on exploring whether distress transmits real costs to a firm's trading partners. We also examine potential losses arising from trade credit. Most importantly, we use a proxy for the likelihood that the trading partner will survive and show that a large portion of the supplier's reaction to the distress announcement is explained by this factor. Finally, we investigate the profitability of suppliers after their distressed partners file for Chapter 11, further sharpening our understanding of how financial distress costs are transmitted through the supply chain. Taken together, our tests provide strong empirical evidence that some companies incur socially costly spillover effects when their trading partners face bankruptcy.

The paper is organized as follows: Section II identifies the set of explanatory variables that we use in our analysis. Section III describes our sample in detail, including our choice of announcement date. In Section IV, we present the results of our analysis of announcement effects on suppliers and customers, including an analysis to determine the source of spillover effects. Section V describes the results of the analysis of realized operating performance for suppliers following the announcement and the effects of distress on trade receivables of suppliers to distressed firms. Section VI concludes.

\section{Cross-Sectional Determinants of Spillover Effect}

\section{A. Information Effect and Credit Costs}

Spillover effects in the supply chain may simply reflect new information about the supplier's or customer's industry. Lang and Stulz (1992) find that firms in the same industry as a bankrupt firm experience abnormal returns around the Chapter 11 filing announcement. Hertzel et al. (2008) document negative and significant abnormal returns to suppliers when their industry rivals have negative returns at their event dates, but they find no evidence of spillover effects when rivals have positive abnormal returns (in fact, the returns to suppliers are positive, although insignificant at their event date when rivals have positive abnormal returns). Thus, it is possible that negative spillover effects may be driven by new information affecting the entire industry. Following Lang and Stulz (1992) and 
Jorion and Zhang (2009), we use the supplier's or customer's industry abnormal return in our analysis to capture the information effect of the news of the filing firm's distress on the industries of its suppliers and customers.

Both financial firms that lend to businesses and suppliers that provide trade credit to their customers face possible credit losses if a customer goes bankrupt. Jorion and Zhang (2009) focus on the expected impact of credit losses by examining the abnormal returns to creditors net of the information effect surrounding Chapter 11 filings. These losses reflect a bad outcome of an investment decision. We use a proxy for the amount of trade credit extended by suppliers to their distressed customers to capture these possible losses. We also examine suppliers' financial statements before, during, and after the Chapter 11 filing for direct evidence on firms' treatment of trade credit.

\section{B. Partner Replacement Costs}

In a perfectly competitive, frictionless market, eliminating a firm should not affect the value of other firms (Lang and Stulz (1992)). However, market imperfections may lead to social costs to suppliers and customers from the loss of a trading partner. Partner replacement costs are the reduced revenues or added costs borne by a supplier or customer associated with fully or partially replacing a failed partner. Lang and Stulz find that benefits accrue to rivals of bankrupt firms. These gains may come at the expense of customers through charging higher prices or through suppliers by demanding lower prices. Alternatively, the gains may come from eliminating a distressed rival that has been charging noncompetitive prices (Weiss and Wruck (1998)). Potential losses to suppliers and customers rise with the degree of dependence on the filing firm (Hertzel et al. (2008)). In addition to direct losses from lost sales or increased input prices, if the filing firm is economically important for its supplier or customer, it may exert bargaining power on its nonfiling trading partners before and during bankruptcy. ${ }^{2}$ We expect the degree of reliance to be economically significant in explaining the level of replacement costs. We use the percentage of sales or purchases with the distressed firm for suppliers and customers, respectively, as our proxy for reliance.

Firms selling specialized or unique goods to or buying specialized goods from the filing firm may suffer negative wealth effects because these suppliers and customers are likely to have made investments specific to the filing firm. Ideally, we would use detailed information about the nature of each supplier-customer relationship to determine the level of relationship-specific investment that might be lost in bankruptcy. We examine firms' 10 -Ks for evidence of specific relationships between suppliers and their distressed partners. Although firms report important relationships and discuss the risks of concentrated supply-chain relationships in broad terms, typically they do not provide detailed information on relationshipspecific investments. Therefore, consistent with existing empirical literature (e.g., Titman (1984), Levy (1985), Titman and Wessels (1988), Bowen, DuCharme, and Shores (1995), Holmstrom and Roberts (1998), Allen and Phillips (2000), Fee,

\footnotetext{
${ }^{2}$ Wilner (2000) presents a model in which dependent suppliers are forced to offer more concessions to the distressed customer during Chapter 11 negotiations if they want to maintain an enduring productmarket relationship. Boone and Ivanov (2012) find evidence that, on average, such strategic-alliance partners experience negative stock price reaction around the filing announcement.
} 
Hadlock, and Thomas (2006), Kale and Shahrur (2007), and Raman and Shahrur (2008)), we conjecture that some of the R\&D expenses of suppliers and customers are attributable to their relationship with the bankrupt firm. We use the ratio of $\mathrm{R} \& \mathrm{D}$ expenditure to sales as the measure of product specialization in our tests.

The distressed firm's industry concentration may affect the profitability of its suppliers and customers. If a filing firm operating in a concentrated industry liquidates, its suppliers have fewer alternatives for rerouting their output, and customers have fewer alternatives for obtaining their inputs. In addition, the filing firm's competitors have greater bargaining power as a result of increased market share and may exert price pressure on suppliers or customers. If the filing firm survives, it may have greater bargaining power over the supplier or customer during the negotiation process and may extract greater concessions because it is more difficult for the supplier to find a substitute customer or for the customer to find a substitute supplier. Lang and Stulz (1992) examine the stock-price effects on rivals to firms that file for Chapter 11 and find that rival firms in industries that are more concentrated receive greater benefit from the removal of a competitor. It may be that some of the gains come from the ability to squeeze suppliers or customers following the removal of a competitor. We use the Herfindahl index for the distressed firm's industry to proxy for industry concentration.

The degree of concentration within the supplier's or customer's industry may also affect partner replacement costs. More concentrated industries are frequently associated with unique product technologies, economies of scale, high barriers to entry, or network effects (demand-side economies of scale, such as in the computer operating system or telephone network industries). These characteristics suggest that firms operating in concentrated industries are likely to face relatively high switching costs if a trading partner is eliminated. Therefore, we also include the supplier's or customer's own industry concentration in our analysis.

High leverage increases the probability of distress in the supplier or customer, leading to higher bankruptcy costs. Opler and Titman (1994) find that highly leveraged firms lose greater market share to their more conservatively financed competitors during industry downturns. Lang and Stulz (1992) investigate the valuation effects of a bankruptcy announcement on the filing firm's industry and find that rivals of the filing firm with higher leverage suffer greater contagion effects. Thus, the replacement cost effects of the filing firm's distress on its suppliers and customers are likely to be amplified in the presence of higher debt levels in the supplier's or customer's own capital structure.

To summarize, all else equal, for both suppliers to and customers of distressed firms, we hypothesize that the expected cost of replacing a bankrupt firm will be higher the greater the reliance on the distressed partner, the greater the level of specialization of the supplier or customer, the more concentrated the industry of the distressed firm, the more concentrated the industry of the supplier or customer, and the more levered the supplier or customer.

\section{Probability of Reorganization of the Filing Firm}

The probability that a firm emerges successfully from Chapter 11 and remains a customer or supplier in the long run is likely to play a major role in determining spillover effects along the supply chain. Even firms that survive often 
undergo partial liquidation in Chapter 11. If it is highly likely that a bankrupt firm will simply restructure its capital with little disruption to its business, its trading partners may experience few or no spillover effects. Lemmon et al. (2009) show that one of the main determinants of whether a firm emerges from Chapter 11 is the type of distress faced by the filing firm. Financially distressed firms are overburdened with debt, but their underlying business models are sound. In contrast, economically distressed firms have very poor operating performance, and despite relatively low (book) leverage, they have difficulty repaying debts. The combination of poor performance and the inability to repay debt implies that economically distressed firms may not be viable at the current scale in the long run even if their leverage is reduced. Lemmon et al. show that a financially distressed filing firm has a higher probability of emerging as a standalone entity from Chapter $11 \mathrm{com}$ pared with an economically distressed firm. Even if an economically distressed firm survives, in their sample, recidivism in the first 3 years after emergence among economically distressed firms is three times as high as that among financially distressed firms. Firms that successfully reorganize often undergo a partial liquidation in bankruptcy. Lemmon et al. find that financially distressed firms experience virtually no change in their asset bases from filing to emergence, whereas economically distressed firms shed almost half of their assets during bankruptcy. Asset reductions during restructuring may reflect the elimination of business lines or generally reduced sales and therefore may adversely affect suppliers and customers even if their distressed trading partners survive. Lemmon et al. show that asset sales in bankruptcy are explained by the same set of variables they use in determining the probability of emergence. Thus, the probability of reorganization not only captures the likelihood of a supplier's or customer's maintaining a relationship but also may capture the scale of that relationship following emergence from Chapter 11. We use Lemmon et al.'s measure of the degree of economic (as compared with financial) distress, their "combined rank" variable, as one factor in determining the probability of emerging successfully from Chapter 11. Larger firms may be more difficult to acquire because of possible financing constraints of buyers and more difficult to sell or liquidate because of the larger asset fire-sale costs (Aghion, Hart, and Moore (1992)). Lemmon et al. (2009) also incorporate a measure of management effectiveness and include industry fixed effects, combining these factors to estimate an overall probability of reorganization for each firm. We hypothesize that the probability of successful reorganization of the filing trading partner is an important determinant of expected replacement costs in the supply chain.

\section{Sample Selection, Data Description, and Distress Announcement Dates}

\section{A. Sample Selection and Data Description}

If a distressed firm is able to restructure without disrupting its business, its trading partners should not experience ill effects of the distress. Therefore, we focus our attention on trading partners of firms that file for Chapter 11 where the possible demise of the trading partner may impose costs on its trading partners. 
We start with the LoPucki Bankruptcy Research Database (http://lopucki.law .ucla.edu/) for our initial sample of 869 Chapter 11 filings between 1980 and 2009. Each of these firms possesses assets of at least $\$ 100$ million (in 1980 dollars) at the time of filing, and each has at least one publicly traded security. About $60 \%$ of the firms that meet our inclusion criteria reorganize (and $40 \%$ do not), which gives us a good sample in which to compare variation in the expected costs of replacing a trading partner. We match the filing firms to all firms reported as customers or suppliers in Compustat's company segment data. The data consist of a text abbreviation of the customers' names for each reporting supplier. We use text-matching code to match the abbreviated customer name with the set of bankrupt firms to form each supplier-filing customer pair. The same code is then used to match the abbreviated customer name to the universe of all firms on Compustat to form each customer-filing supplier pair. We manually inspect every pair to ascertain that the match is accurate. To ensure a reasonable sample size, we look for a match up to 5 years before the filing date (Hertzel et al. (2008)). If multiple matches between the same two firms occur, we choose the one closest to the filing year. ${ }^{3}$

We identify 363 filing firms that have either a supplier or a customer or both. Out of these, we eliminate 64 filing firms because of lack of Center for Research in Security Prices (CRSP) data for the trading partner. A further 27 bankrupt firms are lost because these do not have enough data to calculate the probability of reorganization. Finally, three utility firms drop out of the sample because all of them reorganized successfully, and thus we cannot estimate the probability of reorganization for this category. This leaves us with a final sample of 269 bankruptcies.

The number line in Figure 1 illustrates our dating convention. The distress announcement date, described in Section III.B, is determined based on a news event in the 12 months prior to the Chapter 11 filing. "FYE" indicates fiscal yearend relative to the filing date. The filing date, $F$, occurs between time -1 and time 0 . The distress announcement date occurs sometime between time $x$, which is 12 months before the filing date, and the filing date, $F$. Thus, the distress announcement date occurs after time -2 and before time 0 .

\section{FIGURE 1}

Time Line

"FYE" indicates fiscal year-end dates. Time -1 is the fiscal year-end prior to the filing date, which occurs at time $F$. The distress announcement date occurs between time $x, 12$ months prior to the filing date, and $F$.

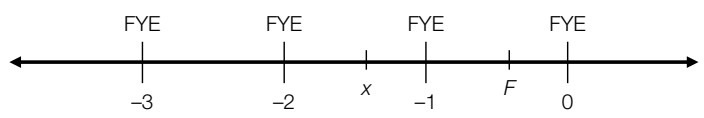

Panel A of Table 1 presents the distribution of filing firms by year, and Panel B presents the distribution of supplier-customer links for each decade. Panel C presents the statistics from Panel B by industry. Of the 269 filing firms, 145 have

\footnotetext{
${ }^{3}$ We check a subsample of the firms to ensure that relationships are still maintained even if the match is made a significant time before the actual filing. We find that relationships still exist between the firm pairs, although the percentage of sales varies from year to year.
} 
TABLE 1

\section{Description of Chapter 11 Sample and Links between Suppliers and Customers}

Filing firms are those that filed for Chapter 11 between 1981 and 2009 with assets of at least $\$ 100$ million in 1980 dollars, at least one publicly traded security, at least one identified publicly traded supplier or customer, and sufficient data to calculate the probability of reorganization. Suppliers and customers of filing firms are identified from firms reporting major customers in Compustat segment data in the 5-year pre-filing period. In Panel E, we proxy for the degree of economic (vs. financial) distress using a measure that is constructed similarly to that of Lemmon et al. (2009) by 1) averaging the firm's year -3 and year -2 industry-adjusted EBITDA-to-assets ratio and ranking this ratio into deciles among all Chapter 11 sample firms, 2) averaging the firm's year -3 and year -2 leverage and ranking this into deciles among all Chapter 11 sample firms, and 3) summing these two decile rankings. The degree of economic distress takes on values from 0 to 18 , with high values having a higher degree of financial distress and low values having a higher degree of economic distress. Following Lemmon et al., we classify firms with values of $0-5$ as economically distressed, firms with values of 14-18 as financially distressed, and the remaining firms as mixed distressed. Panel C classifies filing firms by the 12 Fama-French (1997) industry groups. Our sample contains no utilities.

Panel A. Yearly Distribution of Sample Chapter 11 Filings

\begin{tabular}{|c|c|c|c|c|c|}
\hline \multicolumn{2}{|c|}{ 1981-1989 } & \multicolumn{2}{|c|}{ 1990-1999 } & \multicolumn{2}{|c|}{ 2000-2009 } \\
\hline Filing Year & $\underline{\text { Number of Filings }}$ & Filing Year & $\underline{\text { Number of Filings }}$ & Filing Year & $\underline{\text { Number of Filings }}$ \\
\hline 1980 & 1 & 1990 & 13 & 2000 & 19 \\
\hline 1981 & 1 & 1991 & 10 & 2001 & 31 \\
\hline 1982 & 5 & 1992 & 6 & 2002 & 31 \\
\hline 1983 & 2 & 1993 & 10 & 2003 & 21 \\
\hline 1984 & 3 & 1994 & 2 & 2004 & 10 \\
\hline 1985 & 2 & 1995 & 5 & 2005 & 12 \\
\hline 1986 & 3 & 1996 & 9 & 2006 & 4 \\
\hline 1987 & 4 & 1997 & 4 & 2007 & 3 \\
\hline 1988 & 2 & 1998 & 7 & 2008 & 10 \\
\hline 1989 & 6 & 1999 & 14 & 2009 & 19 \\
\hline
\end{tabular}

Panel B. Distribution of Supplier-Customer Links by Decade

\begin{tabular}{|c|c|c|c|c|c|}
\hline Filing Decade & $\begin{array}{l}\text { Number of Filing Firms with } \\
\text { at Least One Supplier } \\
\text { or One Customer }\end{array}$ & $\begin{array}{l}\text { Number of Filing } \\
\text { Firms with One or } \\
\text { More Suppliers }\end{array}$ & $\begin{array}{c}\text { Average Number of } \\
\text { Suppliers for Each } \\
\text { Filing Firm } \\
\end{array}$ & $\begin{array}{l}\text { f Number of Filing } \\
\text { Firms with One or } \\
\text { More Customers } \\
\end{array}$ & $\begin{array}{c}\text { Average Number of } \\
\text { Customers for Each } \\
\text { Filing Firm } \\
\end{array}$ \\
\hline $1981-1989$ & 29 & 19 & 4.0 & 15 & 1.8 \\
\hline 1990-1999 & 80 & 42 & 2.1 & 53 & 1.9 \\
\hline 2000-2009 & 160 & 84 & 2.5 & 105 & 2.2 \\
\hline Total sample & 269 & 145 & 2.9 & 173 & 1.9 \\
\hline
\end{tabular}

Panel C. Distribution of Sample Chapter 11 Filings by Industry

\begin{tabular}{|c|c|c|c|c|c|}
\hline Industry & $\begin{array}{c}\text { Number of Filing } \\
\text { Firms }\end{array}$ & $\begin{array}{l}\text { Number of Filing } \\
\text { Firms with One or } \\
\text { More Suppliers }\end{array}$ & $\begin{array}{c}\text { Average Number of } \\
\text { Suppliers in Filing } \\
\text { Firm's Portfolio }\end{array}$ & $\begin{array}{l}\text { Number of Filing } \\
\text { Firms with One or } \\
\text { More Customers }\end{array}$ & $\begin{array}{c}\text { Average Number of } \\
\text { Customers in Filing } \\
\text { Firm's Portfolio }\end{array}$ \\
\hline Business equipment & 28 & 16 & 2.8 & 22 & 2.0 \\
\hline Chemicals & 6 & 3 & 1.3 & 4 & 2.8 \\
\hline Durables & 20 & 8 & 8.1 & 18 & 2.9 \\
\hline Energy & 17 & 5 & 7.0 & 15 & 2.0 \\
\hline Health & 6 & 5 & 1.4 & 3 & 1.7 \\
\hline Manufacturing & 51 & 20 & 1.6 & 43 & 2.0 \\
\hline Finance & 9 & 6 & 1.2 & 4 & 1.0 \\
\hline Nondurables & 30 & 8 & 1.6 & 28 & 1.7 \\
\hline Other & 35 & 24 & 1.8 & 15 & 1.9 \\
\hline Shops & 41 & 34 & 2.8 & 8 & 1.8 \\
\hline Telecom & 26 & 16 & 2.1 & 12 & 2.4 \\
\hline
\end{tabular}

Panel D. Distribution of Supplier-Customer Links in the Same SIC Code

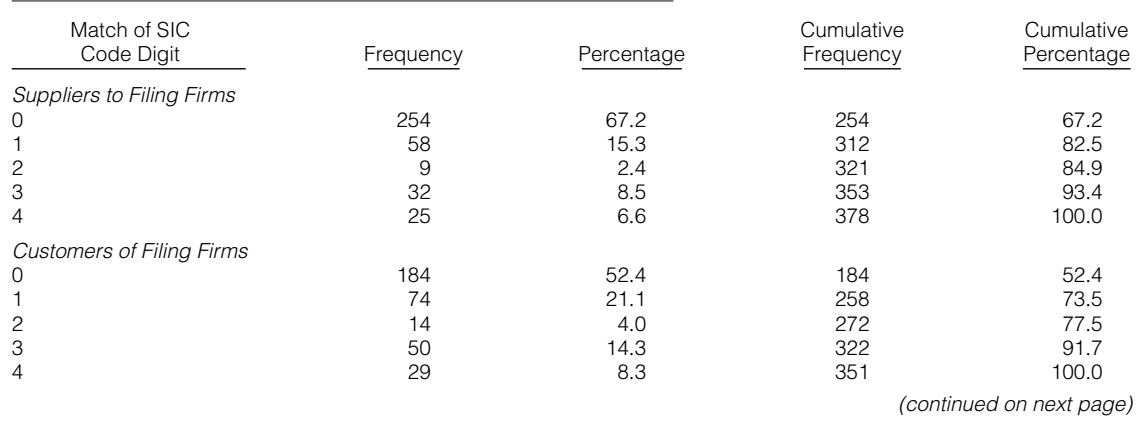


TABLE 1 (continued)

Description of Chapter 11 Sample and Links between Suppliers and Customers

Panel E. Distribution of Economic, Mixed, and Financial Distress of Chapter 11 Filings by Decade

\begin{tabular}{|c|c|c|c|c|c|c|}
\hline \multirow[b]{2}{*}{ Filing Decade } & \multicolumn{3}{|c|}{$\begin{array}{l}\text { Filing Firms with at Least One } \\
\text { Supplier in the Sample }\end{array}$} & \multicolumn{3}{|c|}{$\begin{array}{c}\text { Filing Firms with at Least One } \\
\text { Customer in the Sample }\end{array}$} \\
\hline & $\begin{array}{c}\text { Average } \\
\text { Percentage } \\
\text { Economically } \\
\text { Distressed }\end{array}$ & $\begin{array}{c}\text { Average } \\
\text { Percentage } \\
\text { Mixed } \\
\text { Distressed }\end{array}$ & $\begin{array}{c}\text { Average } \\
\text { Percent } \\
\text { Financially } \\
\text { Distressed }\end{array}$ & $\begin{array}{c}\text { Average } \\
\text { Percentage } \\
\text { Economically } \\
\text { Distressed }\end{array}$ & $\begin{array}{c}\text { Average } \\
\text { Percentage } \\
\text { Mixed } \\
\text { Distressed }\end{array}$ & $\begin{array}{c}\text { Average } \\
\text { Percentage } \\
\text { Financially } \\
\text { Distressed }\end{array}$ \\
\hline 1981-1989 & 16 & 74 & 11 & 29 & 57 & 14 \\
\hline 1990-1999 & 10 & 67 & 24 & 11 & 66 & 23 \\
\hline 2000-2009 & 18 & 63 & 19 & 17 & 67 & 16 \\
\hline
\end{tabular}

at least one supplier, and 173 have at least one customer. The sample of suppliers consists of 378 individual suppliers (an average of about three suppliers per filing firm), and the number of customers equals 351 (an average of about two customers per filing firm). The sample of bankruptcies is concentrated over the 2000-2009 period (about $60 \%$ of the sample). ${ }^{4}$ Panel D tabulates the distribution of industries for suppliers or customers and their distressed trading partners based on Standard Industrial Classification (SIC) digits. The table shows that $67 \%$ of suppliers are in a different industry from their distressed partners at even the 1-digit SIC code level. Only $15 \%$ match at the 3- or 4-digit level. Customers' industries differ from their distressed partners' industries even at the 1-digit level in 52\% of cases, and they match at the 3 - or 4-digit level in only $23 \%$ of cases.

We compute a measure of the degree of economic (as opposed to financial) distress following the method in Lemmon et al. (2009). We sort our sample of bankrupt firms into deciles within sample and number them from 0 to 9 ( 0 being smallest and 9 being largest) based on the industry-adjusted EBITDA-to-assets ratio averaged over year -3 and year -2 and repeat the same process using average leverage. ${ }^{5}$ Industry adjustments to the EBITDA-to-assets ratio are made by subtracting the industry-median ratio of EBITDA to total assets from the sample firm's ratio of EBITDA to total assets. Industry medians are calculated based on 4-digit SIC codes, provided that there are five or more firms in the industry, excluding the sample firm. If the 4-digit SIC code contains fewer than five firms, we define the industry median using the 3 -digit SIC code and continue to the 2-digit level until five firms are found. Leverage is calculated as the ratio of total liabilities to total assets, and the ratio is averaged over year -3 and year -2 . The rankings are then summed, resulting in a proxy for the degree of economic (vs. financial) distress, ranging from 0 to 18. Lemmon et al. (2009) label firms in categories 0

\footnotetext{
${ }^{4}$ We include the bankruptcies of finance and utilities industries in our sample, as do Hertzel et al. (2008). Utilities and finance companies are treated differently in bankruptcy, but since we focus on the effects on their supply chain partners rather than on the filing firm itself, we do not expect their different treatment under Chapter 11 to affect our results. Nevertheless, we repeat our main tests after dropping these firms and find that results remain virtually unchanged.

${ }^{5}$ Because our sample is relatively small, if we do not find data for both years, we use data for 1 year only. We average over year -3 and year -2 relative to filing, because we look for distress dates in the year immediately prior to filing $(-1)$. To ensure that the accounting data used to calculate the probability of reorganization are already known to the market on the distress announcement date, we do not use data from year -1 .
} 
to 5 as economically distressed, label firms in categories 14 to 18 as financially distressed, and label the remaining firms as having a mixed type of distress. In our univariate tests, we use these three classifications. In our multivariate tests, we use the full range of the degree of economic distress proxy.

Panel E of Table 1 shows the distribution of distress type among filing firms by each decade. Across all decades, $68 \%$ of all filing firms for which we identify one or more suppliers suffer from mixed distress, $15 \%$ of the filing firms are economically distressed, and the remaining $17 \%$ are classified as financially distressed. Correspondingly, $63 \%$ of all filing firms for which we identify at least one customer are in the mixed-distress category, $19 \%$ of the firms are economically distressed, and the remaining $18 \%$ are classified as financially distressed.

Table 2 contains the means and medians of the variables used in our analysis for the filing firms, their suppliers, and their customers. We average characteristics over 2 fiscal years to capture sustained characteristics. To ensure that we use variables from before our announcement date, we use data from year -3 and year -2 for the filing firms. For suppliers and customers, we use data from year -2 and year -1 , provided the announcement occurs before year -1 ; if the announcement occurs between year -2 and year -1 for a supplier or customer, we use data from year -3 and year -2 . In each case, if a firm has data for only 1 of the 2 years, we use that year's data.

From a comparison of Panels A, B, and C of Table 2, it is evident that customers are much larger than suppliers and less dependent on their filing trading partners. In our sample, filing firms are almost 6 times larger than their suppliers and only approximately $1 / 50$ th of the size of their customers (median). This pattern is consistent with the results of Banerjee, Dasgupta, and Kim (2008). Publicly traded firms are required to report the identity of any customer that comprises more than $10 \%$ of a firm's consolidated revenues along with the percentage of revenues generated, and they must report whether losing that customer would have a material adverse effect on the firm. ${ }^{6}$

In Panels B and C of Table 2, we measure the reliance of suppliers and customers on the filing firm by the dollar sales generated from the major customer of the reporting firm in the Compustat segment files (CSALE). When using CSALE to measure the degree of reliance of the suppliers on the filing firm, we normalize by the supplier's sales. To capture the percentage of purchases made from the bankrupt firm by a customer, we divide CSALE by the customer's cost of goods sold (COGS). We measure this variable for the year in which the match between the supplier and customer was made from the Compustat data. On average, our

${ }^{6}$ The SEC Web site (http://www.sec.gov/rules/proposed/33-7549.htm) states that "since the adoption of SFAS No. 14, GAAP has required disclosure of revenues from major customers. SFAS No. 131 now [since 1997] requires issuers to disclose the amount of revenues from each external customer that amounts to $10 \%$ or more of its revenue as well as the identity of the segment(s) reporting the revenues. The accounting standards, however, have never required issuers to identify major customers. On the other hand, Regulation S-K Item 101 historically requires naming a major customer if sales to that customer equal $10 \%$ or more of the issuer's consolidated revenues and if the loss of the customer would have a material adverse effect on the issuer and its subsidiaries. Since we continue to believe that the identity of major customers is material information to investors, we propose to retain this Regulation S-K requirement." 
TABLE 2

\section{Descriptive Statistics for Filing Firms and Their Suppliers and Customers}

The sample of filing firms consists of all firms with adequate data with assets of at least $\$ 100$ million (1980 dollars) and at least one publicly traded security filing for Chapter 11 between 1981 and 2009. Suppliers and customers of filing firms are identified through Compustat's segment data. Results are presented using the number of firms for which the data are available for that variable. FILING_FIRM_SIZE is captured by total assets. FILING_FIRM_R\&D_INTENSITY is the ratio of R\&D expense to total assets. Receivables are scaled by sales, and payables are scaled by COGS. FILING_FIRM_INDUSTRY_CONCENTRATION is the average Herfindahl index calculated using all the firms in the same 4-digit SIC code. FILING_FIRM_LEVERAGE is measured as the ratio of total liabilities to total assets. Year -1 is the fiscal year-end prior to the Chapter 11 filing. For filing firms, each of these variables is the average of year -3 and year -2 , provided that data exist for both years; for suppliers and customers, the variables are averaged over the 2 fiscal years prior to the distress date. In Panel A, we proxy for the degree of economic (vs. financial) distress using a measure that is constructed similarly to that of Lemmon et al. (2009) by 1) averaging the firm's year -3 and year -2 industry-adjusted EBITDA-to-assets ratio and ranking this into deciles among all Chapter 11 sample firms, 2) averaging the firm's year -3 and year -2 leverage and ranking this into deciles among all Chapter 11 sample firms, and 3) summing these two decile rankings. DEGREE_OF_ECONOMIC_DISTRESS takes on values from 0 to 18, with high values having a higher degree of financial distress and low values having a higher degree of economic distress. Industry-adjusted EBITDA-to-assets ratio is the average of the sample firm's year -3 and year -2 ratio of EBITDA to total assets minus the industry-median ratio of EBITDA to total assets where both years are available. The industry is defined at the 4-digit SIC level, provided that it contains a minimum of five firms. Otherwise, the industry is defined at the 3-digit or 2-digit SIC level. INDUSTRY_ADJUSTED_OPERATING_PERFORMANCE is computed as the ratio of EBITDA to total assets, with the industry adjustment the same as that in the DEGREE_OF_ECONOMIC_DISTRESS variable. \%_FILING_FIRMS_IN_DISTRESSED_INDUSTRIES is an indicator variable that equals 1 if the stock return of the median firm in the industry is less than $-30 \%$ in the 12 months immediately prior to Chapter 11 filing, and 0 otherwise. \%_FILING_FIRMS_IN_LOW_GDP_YEARS equals 1 if the firm filed for Chapter 11 in any of the years that comprise the lowest quartile of GDP growth over our sample period, and 0 otherwise. \%_SALES_GENERATED_FROM_BANKRUPT_TRADING_PARTNER is the sales made from the bankrupt customer in the year in which the relationship is identified scaled by the total sales of the supplier in that year. \%_PURCHASES_MADE_FROM_BANKRUPT_TRADING_PARTNER is the purchases made from the bankrupt supplier in the year in which the relationship is identified scaled by the total cost of goods sold of the customer in that year.

Variable

No. of Obs. Mean Median

Panel A. Chapter 11 Filing Firm Sample Statistics

FILING_FIRM_SIZE (\$millions)

FILING FIRM R\&D INTENSITY

FILING_FIRM_INDUSTRY_CONCENTRATION

FILING_FIRM_LEVERAGE

FILING_FIRM TRADE RECEIVABLES/SALES

FILING_FIRM_TRADE_PAYABLES/COGS

INDUSTRY_ADJUSTED_OPERATING_PERFORMANCE

DEGREE OF ECONOMIC DISTRESS

$\%$ FILING_FIRMS_IN_DISTRESSED_INDUSTRIES

$\%$ \%ILING_FIRMS_IN_LOW_GDP_YEARS

Panel B. Supplier Sample Statistics

SUPPLIER SIZE (\$millions)

$\%$ SALES_GENERATED_FROM_BANKRUPT_TRADING_PARTNER

SUPPLIER R\&D INTENSITY

SUPPLIER INDUSTRY_CONCENTRATION

SUPPLIER_LEVERAGE

SUPPLIER TOTAL RECEIVABLES/TOTAL SALES

SUPPLIER_TOTAL_PAYABLES/TOTAL_COGS

$\begin{array}{lcc}269 & 3,201 & 650 \\ 269 & 0.011 & 0 \\ 269 & 0.24 & 0.19 \\ 269 & 0.84 & 0.79 \\ 261 & 0.28 & 0.12 \\ 208 & 0.31 & 0.14 \\ 269 & -0.02 & -0.01 \\ 269 & 9.27 & 9 \\ 269 & 30.48 & 0 \\ 269 & 13.01 & 0\end{array}$

Panel C. Customer Sample Statistics

CUSTOMER SIZE (\$millions)

\%_PURCHASES_MADE_FROM_BANKRUPT_TRADING_PARTNER

CUSTOMER_R\&D_INTENSITY

CUSTOMER INDUSTRY CONCENTRATION

CUSTOMER_LEVERAGE

CUSTOMER_TOTAL_RECEIVABLES/TOTAL_SALES

CUSTOMER_TOTAL_PAYABLES/TOTAL_COGS

$\begin{array}{lcc}338 & 1,242 & 109 \\ 369 & 14.4 & 11.0 \\ 378 & 0.04 & 0 \\ 331 & 0.21 & 0.15 \\ 337 & 0.66 & 0.53 \\ 323 & 0.25 & 0.16 \\ 332 & 0.30 & 0.14\end{array}$

suppliers depend on their filing partners for $14 \%$ of sales, whereas customers of our filing firms make $4 \%$ of their purchases from our filing firms. Given the discrepancies in size and reliance between filing firms and their customers, the effects on the customers in our sample may be hard to detect.

The supplier's or customer's R\&D expenditure-to-asset ratio ( $R \& D$ intensity) is used as a measure of product specialization. In all three panels of 
Table 2, industry concentrations are measured using the Herfindahl index of all the firms having the same 4-digit SIC code as the filing firm, customer, or supplier in question. Leverage is measured by the firm's ratio of total liabilities to total assets. We scale receivables by sales and payables by COGS. The other variables in Panel A are used to compute the probability that the filing firm will emerge from bankruptcy as a standalone firm; these are described in the next section.

\section{B. Probability That the Filing Firm Reorganizes}

We estimate the probability that the filing firm reorganizes and emerges as a standalone firm using the logistic model from Lemmon et al. (2009). Means and medians for the variables used in our tests are presented in Table 2. We compute industry-adjusted operating income based on the EBITDA-to-assets ratio using the same industry adjustment as in the proxy for the degree of economic distress. The model also uses Lemmon et al.'s (2009) proxy for the degree of economic distress described earlier. We use an industry-distress indicator variable that is similar to that used by Acharya, Bharath, and Srinivasan (2007) and Lemmon et al. (2009) in the logistic regression. We compute the industry-median (based on 4-digit SIC code) stock return for the 12 months immediately prior to the Chapter 11 filing. If there are fewer than five firms in that 4-digit SIC code, we use the 3-digit (or, if required, 2-digit) SIC code to calculate the industry median. Industries with median returns lower than $-30 \%$ are identified as distressed, with the industry-distress indicator variable equal to 1, and 0 otherwise. Eighty-two $(30.5 \%)$ firms in our sample of filing firms are in a distressed industry. The model also incorporates a control for the effects of economic downturns. A recession indicator variable is set to 1 if the sample firm filed for bankruptcy in a year in which the percentage change in gross domestic product (GDP) was in the bottom quartile of GDP changes over our sample period. In our sample, these years are 1980, 1982, 1991, and 2009. Finally, the ratio of the filing firm's R\&D expenses to assets is used as a measure of the manager's information advantage in Chapter 11. ${ }^{7}$ Table 3 contains two models for computing the probability of reorganization. Model 1 uses the variable for the degree of economic distress, and model 2 uses the components of the degree of economic distress (industry-adjusted operating performance and leverage) separately. Both models are significant at the $1 \%$ level. The model incorporating the degree of economic distress fits slightly better, so we use that version in our subsequent tests. Overall, $60 \%$ of our filing firms reorganize. Individual estimated probabilities of reorganization from the model vary considerably and range between $13.7 \%$ and $95.5 \%$. Figure 2 presents the distribution of estimated probabilities using model 1 in Table 3.

${ }^{7}$ The ratio of R\&D expenses to assets is being used as two different proxies: following Lemmon et al. (2009), we use the ratio of R\&D to sales of the filing firm as a measure of the manager's information advantage for the filing firms. We also use it later as a measure of the product specialization of the supplier or customer of the filing firm. Although the results presented are from using R\&D as a variable in our logit regression, we drop this variable because it is insignificant and redo all tests. Results remain virtually unchanged. Further, these two are not contradictory, because product specialization implies uniqueness of goods produced, in which situation managers would have more firm-specific information than others. 
TABLE 3

Logistic Regressions for the Probability of Reorganization in Chapter 11

\begin{abstract}
Table 3 presents the results from the binomial logistic regressions of Lemmon et al. (2009) where the dependent variable equals 0 if the outcome of Chapter 11 is either liquidation or acquisition ("Liquid/M\&A") and equals 1 if the outcome is reorganization ("Reorganize"). PRE_FILING_INDUSTRY_ADJUSTED_OPERATING_PERFORMANCE is measured as the EBITDA-to-assets ratio of the sample firm minus the industry-median ratio of EBITDA to total assets averaged over year -3 and year -2 where both years are available. Year -1 is the fiscal year-end prior to the Chapter 11 filing. The industry is defined at the 4-digit SIC level, provided that it contains a minimum of five firms. Otherwise, the industry is defined at the 3-digit or 2-digit SIC level. PRE_FILING_LEVERAGE is measured by the ratio of total liabilities to total assets; the ratio is averaged over year -3 and year -2 where data for both years are available. We proxy for the degree of economic (vs. financial) distress using a measure that is constructed similarly to that of Lemmon et al. (2009) by 1) averaging the firm's year -3 and year -2 industry-adjusted ratio of EBITDA to assets and ranking this into deciles among all Chapter 11 sample firms, 2) averaging the firm's year -3 and year -2 leverage and ranking this into deciles among all Chapter 11 sample firms, and 3) summing these two decile rankings. DEGREE_OF_ECONOMIC_DISTRESS takes on values from 0-18, with high values having a higher degree of financial distress and low values having a higher degree of economic distress. The industry-adjusted EBITDA-to-assets ratio is the average of the sample firm's year -3 and year -2 ratio of EBITDA to total assets minus the industry-median ratio of EBITDA to total assets where both years are available. INDUSTRY_DISTRESS is an indicator variable that equals 1 if the stock return of the median firm in the industry is less than $-30 \%$ in the 12 months immediately prior to Chapter 11 filing. LOW_GDP_YEARS equals 1 if the firm filed for Chapter 11 in any of the years that comprise the lowest quartile of GDP growth over our sample period. R\&D_TO_ASSETS is the ratio of R\&D expense to total assets, is averaged over year -3 and year -2 prior to filing, and is used to capture management's information advantage. Industry dummy variables are based on the Fama-French (1997) 12-industry specification. The $z$-statistics for individual coefficients are reported in parentheses. ${ }^{*},{ }^{* *}$, and ${ }^{* \star *}$ indicate significance at the $10 \%, 5 \%$, and $1 \%$ levels, respectively.
\end{abstract}

Variable

Intercept

Liquid/M\&A $=0$ Reorganize $=1$

$\frac{\text { (Model 1) }}{-2.632}$

PRE_FILING_INDUSTRY_ADJUSTED_OPERATING_PERFORMANCE

PRE_FILING_LEVERAGE

DEGREE_OF_ECONOMIC_DISTRESS

SIZE (log(TOTAL_ASSETS))

INDUSTRY_DISTRESS

LOW_GDP_YEARS

R\&D_TO_ASSETS

Industry dummy variables

No. of obs.

Probability $>\chi^{2}$

\begin{tabular}{c} 
Liquid/M\&A $=0$ \\
Reorganize $=1$ \\
$($ Model 2) \\
\hline-2.748 \\
$(-2.75)^{\star \star \star}$ \\
2.569 \\
$(1.56)$ \\
1.341 \\
$(2.31)^{\star \star}$ \\
\\
\\
0.323 \\
$(2.68)^{\star \star \star}$ \\
-0.554 \\
$(-1.71)^{\star}$ \\
0.368 \\
$(0.85)$ \\
-2.547 \\
$(-0.54)$ \\
Yes \\
269 \\
0.0014 \\
\end{tabular}

\title{
C. Distress Announcement Date
}

Very few Chapter 11 filings come as a surprise because most firms try to avoid bankruptcy by restructuring their assets and liabilities. Chapter 11 is often the final step in the resolution of distress (Asquith, Gertner, and Scharfstein (1994)). Hertzel et al. (2008), who also investigate wealth effects in the supply chain, define the pre-filing distress date as the day during the 12 months prior to bankruptcy on which the filing firm has the largest abnormal dollar loss. The abnormal dollar loss is measured as the filing firm's return less the CRSP valueweighted index return multiplied by the market capitalization of the filing firm on the previous day. This method can have several drawbacks.

First, there is no guarantee that any new information about the firm was released on the Hertzel et al. (2008) date. ${ }^{8}$ Second, if there is new information about

\footnotetext{
${ }^{8}$ Hertzel et al. (2008) examine some of their dates manually and verify that these reflect filingfirm-specific events such as debt downgrades, earnings warnings, and missed earnings expectations.
} 


\section{FIGURE 2 \\ Distribution of Probability of Reorganization Estimates}

Figure 2 shows the distribution of reorganization probabilities for our sample of 269 bankruptcy filings estimated using the model by Lemmon et al. (2009). Data for estimating the probability include financial data from the fiscal year-end 2 and 3 years prior to the Chapter 11 filing, industry dummies, and indicator variables for industry distress and low GDP in the filing year. The model and specific variables are discussed in model 1 of Table 3.

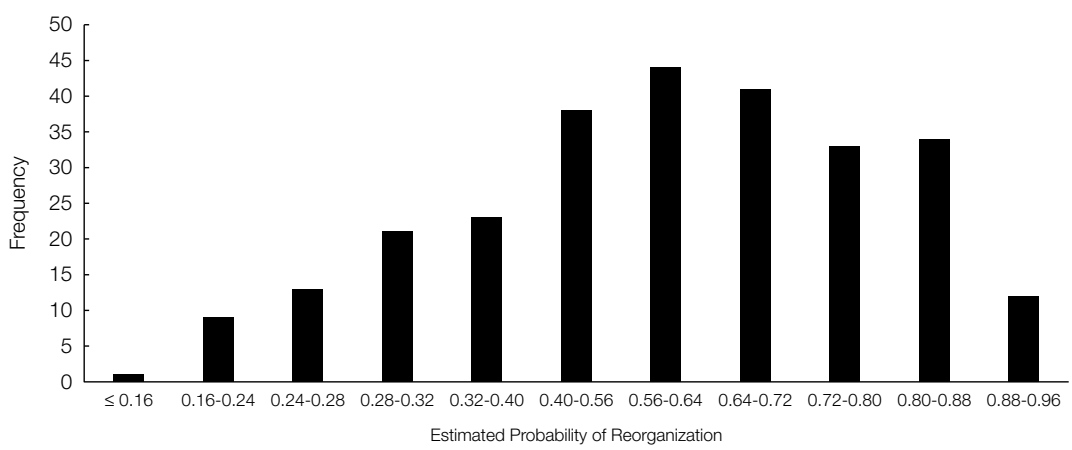

the firm, it may not be unambiguously indicative of distress. The Hertzel et al. method of determining the distress date is associated with earnings announcements in 25 filing firms in our sample $(9 \%) .{ }^{9}$ Third, this procedure may select a date on which a firm experiences a spike in its stock price and the price reverts on the following day, because the high market capitalization of the day before can lead to very large dollar losses for the following day. Finally, many firms cease trading well in advance of a Chapter 11 filing, resulting in incomplete data. ${ }^{10}$ Perhaps for these reasons, Hertzel et al. report an average abnormal return to suppliers on their value-loss date of less than half the magnitude of their reported abnormal return on the Chapter 11 filing date, and the spillover effect is significant at only the $10 \%$ level. In this study, we use a date on which information indicating that the filing firm is in distress is released. Other authors have used similar approaches for identifying key dates in financial distress. Gilson, John, and Lang (1990) and Tashjian, Lease, and McConnell (1996) identify the date on which distressed restructurings start as the date of the first announcement that the firm is renegotiating with creditors, has already renegotiated, or has defaulted.

To identify our distress date, we search for news articles in LexisNexis over the 1 -year period prior to the filing date for each firm. ${ }^{11}$ From these articles, we choose (in order) the following categories: 1) any news mentioning suppliers or

However, when their date identification method is implemented in our sample of filing firms that have return data on this date and have at least one supplier, we find 10 filing firms for which we are unable to find any new information released on or near $(-1$ to +1$)$ that date.

${ }^{9}$ Filing firms are limited to those that have return data on this date and at least one supplier.

${ }^{10}$ Furthermore, Hertzel et al. (2008) select their event date based on a date of maximum market cap loss, making it difficult to determine whether any negative abnormal returns they find are the result of spillover effects or are an outcome of their sample construction process.

${ }^{11}$ In three filings, it was clear that the market knew of distress prior to the 1 -year period before filing. In these three cases, the distress announcement date occurs more than 12 months before the filing date. We ensure that the financial data used to calculate the probability of reorganization for these three firms are known before the news date. 
customers of the filing firm explicitly responding to the distress in the trading partner (e.g., suppliers refusing to extend credit or customers requiring extra warranties); 2) news regarding a failed restructuring attempt, news that the firm is unlikely to recover, or news that the firm is facing distress and will likely fail if restructuring or refinancing does not occur; 3) news that a firm has hired an advisory or investment firm for potential restructuring, fails to make debt payments, or receives a going-concern qualification by its auditor; and finally, 4) any announcement of an attempt at asset restructuring, such as asset sales, mergers, capital expenditure reductions, and layoffs, or an attempt at debt restructuring. If multiple items in any category are available, we take the earliest. For brevity, we refer to these types of news items as 1) trading partner reaction, 2) failure likely, 3) distress onset, and 4) restructuring.

Suppliers and customers have a direct motive to monitor their trading partners. In addition to the loss of future profits, suppliers may also lose any unpaid trade credit. Trade-credit theories posit that this leads sellers to have an incentive to monitor the (filing) customer firm (Smith (1987), Brennan, Maksimovic, and Zechner (1988), Petersen and Rajan (1997), Biais and Gollier (1997), and Burkart and Ellingsen (2004)). Therefore, direct information pertaining to trading partners is our first choice. Choosing dates with news about suppliers or customers gives rise to the concern that announcement effects for suppliers and customers may be driven by information about these firms rather than the distressed customers. However, we find that less than $7 \%$ of our dates for the entire sample of filing firms belong to the first category. Our results remain virtually unchanged when we exclude these observations from our subsequent analysis.

Because many suppliers function as short-term creditors to their customers, they may continue to extend credit even if they know that their trading partners are distressed. Thus, we expect that such suppliers will be affected most strongly when they have already stretched themselves in expectation that their trading partners will restructure successfully and the restructuring fails. In the absence of the first two criteria, we select news that reflects the onset of distress, such as missed debt payments or hiring an advisory firm for restructuring. We use these because they either appear before any restructuring attempts are made or are the very first steps in the restructuring process. As our last choice, we pick those news stories that indicate that an attempt at asset or liability restructuring has been made, because these do not constitute unambiguously bad news for the trading partners. In the occasional case where there is no reported attempt at a restructuring before filing, we use the filing or the filing announcement as the onset of distress.

For the sample of bankrupt firms that have one or more suppliers, the dates are distributed across groups as follows: supplier reaction, 8\%; failure likely, $30 \%$; distress onset, 36\%; restructuring, $14 \%$; and for $11 \%$, we use the filing date. Correspondingly, for the sample of bankrupt firms that have one or more customers, the dates are distributed between the category types as follows: customer reaction, 5\%; failure likely, 17\%; distress onset, 57\%; restructuring, $13 \%$; and for $8 \%$, we use the filing date. We also repeat the date choice process for our subsample of Chapter 11 filings for which we can identify the date when the possibility of bankruptcy was first mentioned specifically by the distressed firm itself 
or by analysts or other market participants (and not suppliers to the filing firm). ${ }^{12}$ We find that our regression estimates remain qualitatively unchanged.

We are able to compare our information-based distress dates (henceforth, the "distress announcement date") to the date in Hertzel et al. (2008) (henceforth, the "value-loss date") for 188 firms in our sample. ${ }^{13}$ Of those firms for which we are able to identify the value-loss date, $145(77 \%)$ have value-loss dates that precede our information-based distress announcement dates, 19 firms (10\%) have distress announcement and value-loss dates that coincide, and 24 (13\%) have value-loss dates that occur later than the distress announcement date. On average (median), Hertzel et al.'s value-loss date occurs 99 (96) days before our distress announcement date. As firms move toward bankruptcy, their market capitalization becomes smaller as a result of falling stock prices, which tends to lead to earlier value-loss dates.

\section{Determinants of Spillover Effects in the Supply Chain}

\section{A. Distress Announcement Abnormal Returns to Suppliers and Customers}

Average distress announcement and filing-period cumulative abnormal returns to suppliers over a 5-day window centered on the distress announcement and the Chapter 11 filing date are presented in Table 4, Panel A. We compute abnormal returns using the market-adjusted returns method (Brown and Warner (1985)), in which the daily abnormal return is the firm-specific return minus the CRSP value-weighted market return. For each filing company, we form equalweighted portfolios of all its suppliers. The average supplier return is the simple average of these portfolio returns. The abnormal return is $-7.3 \%$ on the distress announcement date, which is significantly different from 0 at the $1 \%$ level. We obtain a cumulative abnormal return (CAR) of $-1.7 \%$ (significant at the $1 \%$ level) for the CAR around the value-loss date.

Table 4 also presents subsample results for Lemmon et al.'s (2009) classification into economically, mixed, or financially distressed firms. As the distress type changes from economic to financial, the abnormal returns decrease in magnitude. The CAR for the 5-day distress announcement period is a statistically significant $-12.3 \%$ for economically distressed firms, whereas for financially distressed firms, the CAR is an insignificant $-0.8 \% .{ }^{14}$ The corresponding CARs for the value-loss period (not tabulated) are $-2.7 \%$ and $5.7 \%$ (both insignificant). The distress announcement date CAR for the mixed type of distressed firms are in the middle, with a significant $-7.5 \%$ CAR $(-4.5 \%$ during the value-loss period,

\footnotetext{
${ }^{12} \mathrm{We}$ focus on the filing firms that have suppliers because in our data, customers of filing firms seldom have any news related to their distressed suppliers. All of our dates in this category involve suppliers rather than customers.

${ }^{13}$ Stock prices are unavailable for many firms in the period leading up to a Chapter 11 filing, precluding identifying the value-loss date.

${ }^{14}$ In this and subsequent panels where we divide the sample by distress type or probability of reorganization, we eliminate extreme outliers because the subsamples are small. This results in eliminating a total of between 0 and 3 outliers across all three subsamples, depending on the table. (The largest number of outliers in any subgroup is 2.)
} 
TABLE 4

CARs to Suppliers and Customers of Bankrupt Firms over Distress Announcement Date

Table 4 contains average distress-period supplier and customer CARs. We identify suppliers and customers by examining firms reporting major customers in Compustat segment data in the 5 years prior to sample firms' Chapter 11 filings. We form equal-weighted customer and supplier portfolios from the individual customers and suppliers for each filing. The distress day is the first date with major news of financial distress in the 12 months prior to filing. Additional details are given in Section III. Suppliers and customers are grouped into distress type using the measure for the degree of economic distress. We proxy for the degree of economic (vs. financial) distress using a measure that is constructed similarly to that of Lemmon et al. (2009), as described in Table 3, or by the probability of reorganization based on model 1 in Table 3 . Firms with a reorganization probability of less than or equal to 0.40 are classified as low-probability firms, firms with a reorganization probability of 0.80 or higher are classified as high-probability firms, and the remaining firms are classified as moderate-probability firms. The abnormal returns are cumulated for days -2 to +2 relative to the distress announcement date, and daily

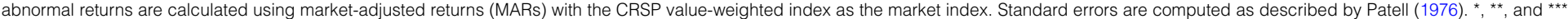
indicate that the average is significantly different from 0 (using a 2 -sided $t$-test) at the $10 \%, 5 \%$, and $1 \%$ levels, respectively.

Panel A. Supplier Average CARs for Distress Announcement Date

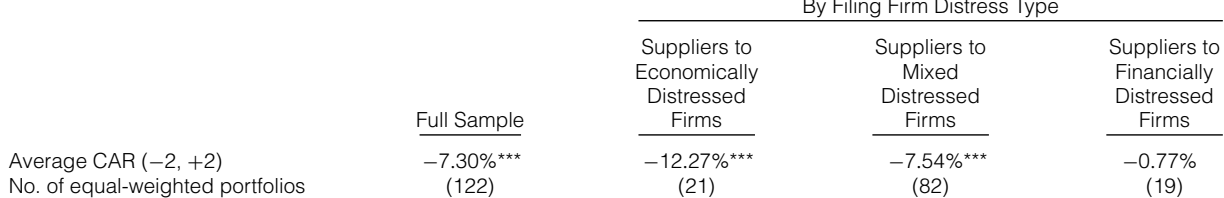

Panel B. Customer Average CARs for Distress Announcement Date

\begin{tabular}{|c|c|c|}
\hline & Full Sample & $\begin{array}{c}\text { Customers to } \\
\text { Economically } \\
\text { Distressed } \\
\text { Firms } \\
\end{array}$ \\
\hline $\begin{array}{l}\text { Average CAR }(-2,+2) \\
\text { No. of equal-weighted portfolios }\end{array}$ & $\begin{array}{c}-1.36 \% \%^{\star \star \star} \\
(150)\end{array}$ & $\begin{array}{c}-2.02 \% \\
(26)\end{array}$ \\
\hline
\end{tabular}

By Filing Firm Distress Type

\begin{tabular}{cc}
$\begin{array}{c}\text { Customers to } \\
\text { Mixed } \\
\text { Distressed } \\
\text { Firms }\end{array}$ & $\begin{array}{c}\text { Customers to } \\
\text { Financially }\end{array}$ \\
\hline $\begin{array}{c}-1.04 \%^{*} \\
(98)\end{array}$ & $\begin{array}{c}\text { Distressed } \\
\text { Firms }\end{array}$ \\
& $\begin{array}{c}-1.51 \% * \star \\
(26)\end{array}$ \\
\hline
\end{tabular}

\section{By Probability of Reorganization Type}

\begin{tabular}{|c|c|c|}
\hline $\begin{array}{c}\text { Suppliers to } \\
\text { Low- } \\
\text { Probability } \\
\text { Firms }\end{array}$ & $\begin{array}{c}\text { Suppliers to } \\
\text { Moderate- } \\
\text { Probability } \\
\text { Firms }\end{array}$ & $\begin{array}{c}\text { Suppliers to } \\
\text { High- } \\
\text { Probability } \\
\text { Firms }\end{array}$ \\
\hline$-19.19 \%^{\star \star \star}$ & $-5.56 \%^{\star \star \star}$ & $-1.12 \%$ \\
\hline
\end{tabular}

(20)
By Probability of Reorganization Type

\begin{tabular}{|c|c|c|}
\hline $\begin{array}{l}\text { Customers to } \\
\text { Low- } \\
\text { Probability } \\
\text { Firms }\end{array}$ & $\begin{array}{c}\text { Customers to } \\
\text { Moderate- } \\
\text { Probability } \\
\text { Firms }\end{array}$ & $\begin{array}{l}\text { Customers to } \\
\text { High- } \\
\text { Probability } \\
\text { Firms }\end{array}$ \\
\hline $\begin{array}{c}-3.25 \% * \\
(24)\end{array}$ & $\begin{array}{c}-1.00 \% \%^{* *} \\
(101)\end{array}$ & $\begin{array}{c}-0.77 \% \\
(25)\end{array}$ \\
\hline
\end{tabular}


significant at the $1 \%$ level). Finally, we split our sample into three groups based on the probability of reorganization. We conjecture that a firm whose trading partner survives and continues to operate at a predistress level is unlikely to bear heavy partner replacement costs. Therefore, we expect smaller spillover effects for firms whose trading partners have a high probability of reorganizing and larger spillover effects for firms whose trading partners are unlikely to survive bankruptcy, all else equal. We classify firms with an estimated reorganization probability of 0.4 or less as low-probability firms, firms with an estimated reorganization probability above 0.8 as high-probability firms, and the remainder as having moderate reorganization probability. These cut points produce similarly sized subsamples as those using the financially, economically, and mixed distress types. The low-probability group has an even more negative announcement reaction than the economically distressed firms $(-19.2 \%)$. The moderate group's abnormal return is negative and significant (CAR of $-5.6 \%$ ), and the high-probability group has an announcement effect of $-1.1 \%$, which is not statistically different from 0 .

Panel B of Table 4 shows CARs for equal-weighted customer portfolios for the 5-day period surrounding the distress announcement date. The overall customer sample has significant negative returns $(-1.4 \%$, significant at the $1 \%$ level) around the distress announcement date. Although the effect is smaller than that of the supplier group, it is economically significant, with a median dollar loss of \$37.5 million over the event window (untabulated). Panel B of Table 4 also contains CARs for the economically, mixed, and financially distressed subsamples based on the filing firm's classification. Although largest in magnitude, the results for the customers of the economically distressed group are insignificantly different from 0 . The financially distressed group has negative and significant CARs, and the mixed distress group has marginally significant CARs. The effects of the distress announcement date for the estimated reorganization probability groups decrease in magnitude as the probability of emergence increases. The low-probability group has announcement returns of $-3.3 \%$ (significant at the $10 \%$ level), the moderate-probability group has announcement returns of $-1.0 \%$ (significant at the $5 \%$ level), and the high-probability group has a return of $-0.8 \%$ (not statistically significant). Given the relatively large size of our customers relative to the filing firms and the relatively low reliance of customers on the filing firms, it is not surprising that the spillover effects are smaller for our customer sample.

Hertzel et al. (2008) do not find significant abnormal returns for the customer sample and speculate that perhaps distress flows from customers to filing firms. Our results suggest that spillover effects flow both up and down the supply chain. Our sample sizes are very close to Hertzel et al.'s, and we find similar results to theirs when using their methodology to identify the event date. By performing our event study on a date on which relevant information is released rather than selecting a date based on stock price movements, it appears that we are able to pinpoint spillover effects more precisely.

\section{B. Determinants of Supplier Spillover Effects}

In Table 5, we explore the cross-sectional determinants of supplier (Panel A) and customer (Panel B) cumulative abnormal returns over the filing firm's distress announcement period. The dependent variable in the regressions is the cumulative 
abnormal return around the distress announcement date of individual suppliers (Panel A) or individual customers (Panel B). Because the individual suppliers to or customers of a particular filing customer are not independent, the $t$-statistics presented are based on clustered standard errors that control for clustering by industry and the month of the year. ${ }^{15}$

\title{
TABLE 5
}

\section{Cross-Sectional Determinants of CARs to Suppliers and Customers of Bankrupt Firms}

\begin{abstract}
Table 5 consists of ordinary least squares (OLS) regressions where the dependent variable is the CAR to suppliers (Panel A) and customers (Panel B) of firms that file for bankruptcy. The CARs are calculated over a 5-day period centered on the distress announcement date. SUPPLIER_LEVERAGE is calculated as the average of the supplier's ratio of total liabilities to total assets at year -1 and year -2 relative to filing. SUPPLIER_R\&D_INTENSITY is R\&D expenses/total assets for each supplier calculated as the average ratio of R\&D expenses to total assets at year -1 and year -2 relative to filing. FILING CUSTOMER INDUSTRY CONCENTRATION is the Herfindahl index calculated for each filing firm using all the firms in the same 4-digit SIC code, and SUPPLIER_INDUSTRY_CONCENTRATION is computed similarly. FILING_CUSTOMER_PROBABILITY_OF_REORGANIZATION is taken from the predicted values of the logistic regression presented in model 1 of Table 3. \% SALES_FROM_DISTRESSED_CUSTOMER is computed as supplier sales generated from the filing firm in the year in which the relationship is identified between the firms scaled by the total sales of the supplier in that year. SUPPLIER_RECEIVABLES_FROM_DISTRESSED_CUSTOMER (Panel A) are estimated by multiplying the percentage of the supplier's sales generated by the filing customer by the average trade receivables in year -2 and year -1 relative to filing, and customer payables are computed analogously (Panel B). SUPPLIER_INDUSTRY_ABNORMAL_RETURN (Panel A) and CUSTOMER_INDUSTRY_ABNORMAL_RETURN (Panel B) are calculated using all firms in the same 3-digit SIC code as the relevant supplier or customer, excluding the sample firm. The $t$-statistics reported in parentheses control for clustering effects resulting from supplier industry and month of the year. ${ }^{*}{ }^{* *}$, and ${ }^{* * *}$ indicate significance at the $10 \%, 5 \%$, and $1 \%$ levels, respectively. The dependent variable is the suppliers' (Panel A) or customers' (Panel B) CAR for days -2 to +2 relative to the distress date of the bankrupt firm and is calculated using MARs with the CRSP value-weighted index as the market index.
\end{abstract}

Panel A. Suppliers to Bankrupt Firms

Dependent Variable: CAR from $(-2,+2)$ for Individual Suppliers around the Distress Announcement Date

\begin{tabular}{|c|c|c|c|c|c|c|c|}
\hline \multirow[b]{2}{*}{ Variable } & \multicolumn{7}{|c|}{ Model } \\
\hline & 1 & 2 & 3 & 4 & 5 & 6 & 7 \\
\hline Intercept & $\begin{array}{l}-0.199 \\
(-3.51)^{\star \star *}\end{array}$ & $\begin{array}{l}-0.174 \\
(-3.12)^{\star \star \star}\end{array}$ & $\begin{array}{l}-0.120 \\
(-2.06)^{\star \star}\end{array}$ & $\begin{array}{l}-0.054 \\
(-4.12)^{\star \star \star}\end{array}$ & $\begin{array}{l}-0.132 \\
(-2.07)^{\star \star}\end{array}$ & $\begin{array}{l}-0.165 \\
(-2.60)^{\star \star *}\end{array}$ & $\begin{array}{l}-0.122 \\
(-2.03)^{\star *}\end{array}$ \\
\hline $\begin{array}{l}\text { FILING_CUSTOMER_PROBABILITY_ } \\
\text { OF_REORGANIZATION }\end{array}$ & $\begin{array}{l}0.214 \\
(2.82)^{\star * *}\end{array}$ & $\begin{array}{l}0.234 \\
(3.08)^{\star \star \star}\end{array}$ & $\begin{array}{l}0.240 \\
(3.56)^{\star \star \star}\end{array}$ & & $\begin{array}{l}0.231 \\
(3.00)^{\star \star \star}\end{array}$ & $\begin{array}{l}0.224 \\
(3.21)^{\star \star *}\end{array}$ & $\begin{array}{l}0.241 \\
(3.46)^{\star * *}\end{array}$ \\
\hline \%_SALES_FROM_DISTRESSED_CUSTOMER & & $\begin{array}{l}-0.265 \\
(-6.55)^{\star \star \star}\end{array}$ & $\begin{array}{l}-0.274 \\
(-5.87)^{\star \star \star}\end{array}$ & & $\begin{array}{l}-0.259 \\
(-5.92)^{\star \star \star}\end{array}$ & & $\begin{array}{l}-0.247 \\
(-3.91)^{\star \star *}\end{array}$ \\
\hline SUPPLIER_R\&D_INTENSITY & & & $\begin{array}{l}-0.176 \\
(-3.67)^{\star \star \star}\end{array}$ & & $\begin{array}{l}-0.174 \\
(-3.07)^{\star \star \star}\end{array}$ & $\begin{array}{l}-0.210 \\
(-3.21)^{\star \star \star}\end{array}$ & $\begin{array}{l}-0.180 \\
(-3.43)^{* * *}\end{array}$ \\
\hline $\begin{array}{l}\text { FILING_CUSTOMER_INDUSTRY } \\
\text { CONCENTRATION }\end{array}$ & & & $\begin{array}{l}0.054 \\
(1.33)\end{array}$ & & $\begin{array}{l}0.065 \\
(1.31)\end{array}$ & $\begin{array}{l}0.060 \\
(1.50)\end{array}$ & $\begin{array}{l}0.048 \\
(1.17)\end{array}$ \\
\hline SUPPLIER_INDUSTRY_CONCENTRATION & & & $\begin{array}{l}-0.057 \\
(-2.00)^{\star \star}\end{array}$ & & $\begin{array}{l}-0.040 \\
(-1.06)\end{array}$ & $\begin{array}{l}-0.039 \\
(-1.05)\end{array}$ & $\begin{array}{l}-0.053 \\
(-1.68)^{*}\end{array}$ \\
\hline SUPPLIER_LEVERAGE & & & $\begin{array}{l}0.003 \\
(0.09)\end{array}$ & & $\begin{array}{c}0.021 \\
(0.68)\end{array}$ & $\begin{array}{l}0.002 \\
(0.07)\end{array}$ & $\begin{array}{l}0.001 \\
(0.03)\end{array}$ \\
\hline SUPPLIER_SIZE & & & $\begin{array}{c}-0.010 \\
(-2.52)^{\star \star}\end{array}$ & & $\begin{array}{l}-0.009 \\
(-1.99)^{\star \star}\end{array}$ & $\begin{array}{c}-0.007 \\
(-1.63)^{\star}\end{array}$ & $\begin{array}{c}-0.010 \\
(-2.36)^{\star \star}\end{array}$ \\
\hline $\begin{array}{l}\text { SUPPLIER_INDUSTRY_- } \\
\text { ABNORMAL_RETURN }\end{array}$ & & & & $\begin{array}{c}0.677 \\
(1.55)\end{array}$ & $\begin{array}{c}0.409 \\
(1.41)\end{array}$ & & \\
\hline $\begin{array}{l}\text { SUPPLIER_RECEIVABLES_FROM_ } \\
\text { DISTRESSED_CUSTOMER }\end{array}$ & & & & & & $\begin{array}{l}-0.051 \\
(-5.68)^{\star * *}\end{array}$ & $\begin{array}{l}-0.026 \\
(-1.74)^{*}\end{array}$ \\
\hline $\begin{array}{l}\text { No. of obs. } \\
p \text {-value of } F \text {-statistic } \\
\text { Adj. } R^{2}\end{array}$ & $\begin{array}{c}270 \\
<0.0001 \\
0.083\end{array}$ & $\begin{array}{c}262 \\
<0.0001 \\
0.149\end{array}$ & $\begin{array}{c}262 \\
<0.0001 \\
0.171\end{array}$ & $\begin{array}{r}240 \\
0.004 \\
0.030\end{array}$ & $\begin{array}{c}233 \\
<0.0001 \\
0.176\end{array}$ & $\begin{array}{c}251 \\
<0.0001 \\
0.123\end{array}$ & $\begin{array}{c}251 \\
<0.0001 \\
0.170\end{array}$ \\
\hline
\end{tabular}

\footnotetext{
${ }^{15}$ Industry is defined as 2-digit SIC code. Month of the year is used so that all suppliers for a particular bankruptcy are clustered because the filing date is the same for all. We repeat the analysis by forming portfolios of all suppliers for each filing firm and repeat the analysis again with firm-level
} 
TABLE 5 (continued)

Cross-Sectional Determinants of CARs to Suppliers and Customers of Bankrupt Firms

Panel B. Customers of Bankrupt Firms

Dependent Variable: CAR from $(-2,+2)$ for Individual Customers of Filing Firms around the Distress Announcement Date

\begin{tabular}{|c|c|c|c|}
\hline \multirow[b]{2}{*}{ Variable } & \multicolumn{3}{|c|}{ Model } \\
\hline & 1 & 2 & 3 \\
\hline Intercept & $\begin{array}{l}-0.037 \\
(-1.29)\end{array}$ & $\begin{array}{c}-0.011 \\
(-1.77)^{*}\end{array}$ & $\begin{array}{l}-0.023 \\
(-0.90)\end{array}$ \\
\hline FILING_SUPPLIER_PROBABILITY_OF_REORGANIZATION & $\begin{array}{c}0.003 \\
(0.11)\end{array}$ & & $\begin{array}{l}-0.002 \\
(-.008)\end{array}$ \\
\hline \%_PURCHASES_FROM_FILING_SUPPLIER & $\begin{array}{l}-0.069 \\
(-2.89)^{\star \star \star}\end{array}$ & & $\begin{array}{l}-0.066 \\
(-3.65)^{\star * *}\end{array}$ \\
\hline CUSTOMER_R\&D_INTENSITY & $\begin{array}{l}-0.446 \\
(-7.32)^{\star \star *}\end{array}$ & & $\begin{array}{l}-0.387 \\
(-7.49)^{* * *}\end{array}$ \\
\hline FILING_SUPPLIER_INDUSTRY_CONCENTRATION & $\begin{array}{c}0.012 \\
(0.80)\end{array}$ & & $\begin{array}{c}0.019 \\
(1.33)\end{array}$ \\
\hline CUSTOMER_INDUSTRY_CONCENTRATION & $\begin{array}{r}0.001 \\
(0.03)\end{array}$ & & $\begin{array}{r}0.004 \\
(-0.20)\end{array}$ \\
\hline CUSTOMER_LEVERAGE & $\begin{array}{c}0.002 \\
(0.10)\end{array}$ & & $\begin{array}{l}-0.013 \\
(-0.73)\end{array}$ \\
\hline CUSTOMER_SIZE & $\begin{array}{c}0.003 \\
(1.36)\end{array}$ & & $\begin{array}{c}0.003 \\
(1.53)\end{array}$ \\
\hline CUSTOMER_INDUSTRY_ABNORMAL_RETURN & & $\begin{array}{c}0.318 \\
(2.44)^{\star \star}\end{array}$ & $\begin{array}{c}0.319 \\
(2.52)^{\star \star}\end{array}$ \\
\hline $\begin{array}{l}\text { No. of obs. } \\
p \text {-value of } F \text {-statistic } \\
\text { Adj. } R^{2}\end{array}$ & $\begin{array}{c}273 \\
<0.0001 \\
0.181\end{array}$ & $\begin{array}{c}281 \\
<0.0001 \\
0.049\end{array}$ & $\begin{array}{r}264 \\
<0.0001 \\
0.222\end{array}$ \\
\hline
\end{tabular}

Model 1 in Table 5 examines the impact of the probability of reorganization (from model 1 in Table 3 ) on CARs around the distress announcement date. The estimated coefficient on the probability of reorganization is positive and both economically and statistically significant. A $10 \%$ lower probability of reorganization is associated with a $2 \%$ drop in the CAR over the 5-day period. Multiplying the coefficient by the median market capitalization of the supplier firm sample translates to an approximate loss of $\$ 24.5$ million ( $\$ 185$ million mean) over 5 days for a representative firm. The model suggests that if the bankrupt firm has a sufficiently high probability of reorganizing successfully, its supplier may not experience any negative wealth effects: the intercept is -0.20 , and the coefficient on the reorganization probability is 0.21 . The sum of these coefficients is statistically indistinguishable from 0 . In model 2 , we add our proxy for the level of supplier dependence on a bankrupt customer. The estimated coefficient for the percentage of sales generated by the filing customer is strongly negative and significant. Together, our measures of the probability of reorganization and reliance explain nearly $15 \%$ of the variation in abnormal returns.

Model 3 of Table 5, our base model, adds the other independent variables designed to capture expected partner replacement costs. ${ }^{16}$ The coefficient of R\&D

fixed effects for filing firms with at least five suppliers. The results are a bit weaker given the reduced sample size but qualitatively similar.

${ }^{16}$ If the suppliers are themselves operating in distressed industries, it may magnify the impact of a partner's distress. In addition to the results here, we also add an indicator for the filing firm's distress to our base specification (model 3) and an analogously defined distress indicator for the nonfiling sup- 
intensity is significant and negative. This is consistent with the evidence provided by Titman and Wessels (1988) and Banerjee et al. (2008): a higher level of product specialization and the consequent higher level of relationship-specific investments in the trading relationship lead to greater costs in switching to a new partner. We find evidence that the supplier's industry concentration affects its abnormal returns. As hypothesized in the previous section, the more competitive the supplier's industry, the more negative the wealth effect on the supplier. We add the supplier's $\log$ of total assets to control for any size effects and find that the larger the firm, the more negative the CAR. Neither the distressed customer's industry concentration nor supplier leverage is statistically significant in explaining the CARs to suppliers.

In unreported results, we repeat models 1 through 3 of Table 5, replacing the probability of reorganization with Lemmon et al.'s (2009) measure of the degree of economic distress. In all three regressions, the coefficient is positive and significant, indicating that more financially distressed firms impose fewer costs on their trading partners. However, the $R^{2}$ values of the regressions are substantially lower than those for the comparable regressions using the probability of distress, and in model 1, the intercept does not equal the coefficient on the variable for the degree of distress. Although the degree of distress is an important factor in our estimates of the likelihood of reorganizing, it appears that the probability of reorganization of the distressed firm is a better predictor of the market's response to the distress announcement, reinforcing our hypothesis that expected replacement costs are a key driver of spillover effects.

Model 4 of Table 5 looks at the information effect alone, and model 5 adds our proxy for information to the base model. Although the coefficients on the industry-abnormal return are positive, they are not statistically significant in either regression ( $t$-statistics of 1.55 and 1.41 , respectively). Although we control for industry effects, it is possible that the information is specific to the web of firms in a particular supply chain. We repeat model 5 for the subsample of filing firms with five or more suppliers (not shown in the table). This subsample consists of 17 filing firms and 131 suppliers. For each supplier, we replace the industry-abnormal return with the abnormal return for all other suppliers for the associated filing firm in our sample, excluding the specific supplier. The coefficient on the probability of reorganization becomes insignificant (which is not surprising given that there are only 17 filing firms); other variables remain significant, and the information variable's coefficient is still insignificant. Thus, the abnormal return to suppliers around the distress announcement date appears to be explained in the cross section by the expected cost of replacing the distressed partner rather than by information.

Finally, we examine whether the negative CARs surrounding the bankrupt firm's distress date can be explained by its supplier's own outstanding trade receivables to explore whether credit costs are an important determinant of spillover costs. The potential loss to the supplier is equal to the losses attributable to past

plier's industry. We find that, in addition to the probability of reorganization, the filing firm's industry distress is significant (coefficient: -0.06 ) but does not reduce the coefficient on the probability of reorganization significantly. The indicator for the supplier's industry distress is insignificant (coefficient: -0.05 ). Adding both of these leads to an increase of $1.49 \%$ in the Adj. $R^{2}$ value of the regression. 
loans made to the filing customer (in the form of trade credit) plus the present value of future lost sales. In performing our tests, we first calculate a proxy for the normalized trade receivables outstanding with respect to the filing customer as follows: percentage of supplier's sales generated from the filing customer $\times$ (supplier's trade receivables/supplier's sales).

The results from adding this variable to the base model from model 3 in Table 5 are shown in models 6 and 7 . Model 6 includes our proxy for trade credit but excludes the percentage of sales from the distressed customer, which forms part of our proxy. The supplier receivables variable is significantly negative ( $t$-statistic of -5.68), but the $R^{2}$ value of the model drops from 0.17 in our base case to 0.12 . In model 7 , the original percentage of the supplier's sales to the filing customer is also included. This accounts for the portion of the loss that the supplier expects as a result of the probability of lower future cash flows because of lost sales. As shown in model 7, the total receivables variable is negative but only marginally significant $(t$-statistic $=-1.74)$. The magnitude of the coefficient of the total sales percentage to the filing customer variable is now marginally smaller compared with model 3 but is still significant $(t$-statistic $=-3.91)$. This suggests that although higher amounts of receivables due from the filing customer are interpreted by the market as a weak negative sign, greater losses are anticipated from expected partner replacement costs. ${ }^{17}$

Our relatively weak results for the impact of credit costs compared with those of Jorion and Zhang (2009) may be attributable to differences in sample construction. They identify their sample from the 20 largest unsecured creditors at the time of the Chapter 11 filing. Further, Jorion and Zhang (2009) do not include variables designed to capture trading partner replacement costs in their regressions, so our results are not comparable. We follow Jorion and Zhang (2009) and examine the list of large unsecured creditors provided by the filing firms in our sample at the time they file for Chapter 11. Typically, the list contains about 20 creditors, although firms in our sample list as few as 5 and as many as 100 unsecured creditors. In some cases, the list exclusively consists of banks serving as trustees for various unsecured debt issues. In other cases, the list contains quite a few trade creditors. The list identifies the name of the unsecured creditor, the type of debt (e.g., public debt or trade credit), and the estimated amount of the claim. Of the 145 bankrupt firms with at least one supplier, we are able to obtain the list of large unsecured creditors for half (73). Of our initial sample of 378 suppliers, 202 of them are from firms for which we have a list of large unsecured creditors. Only 12\% (24 firms) of these 202 suppliers appear on the list. In Section V.B, we examine trade-credit losses more directly based on information reported in U.S. Securities and Exchange Commission (SEC) filings.

Trade credit is often treated differently from other unsecured claims in Chapter 11. Firms in Chapter 11 typically continue operating and often petition to pay suppliers in the ordinary course of business, making trade credit less vulnerable

\footnotetext{
${ }^{17}$ In unreported results, we repeat our baseline model (model 3) using the CARs for the value-loss date and find insignificant results. We also repeat all of our tests after excluding observations where the supplier and filing firm are in similar industries (i.e., where their SIC codes match at the 3- or 4-digit level) from our regressions and find that results remain qualitatively unchanged.
} 
to write-offs than other forms of unsecured credit. Although Franks and Torous (1994) do not report recovery rates for trade creditors, they do report that trade creditors in Chapter 11 receive $98.6 \%$ of their recovery in the form of cash, as compared with other junior creditors, who receive $10.5 \%$ of their recovery in cash. Other creditors are not permitted to receive payments during Chapter 11. Thus, Chapter 11's special treatment of trade creditors is likely to reduce potential spillover costs arising from credit losses significantly.

To summarize, we find that in the cross section, abnormal returns to suppliers are associated strongly with some of our proxies for expected replacement costs, including the probability of reorganization, retooling costs, and the degree of reliance. In contrast, our proxies for capturing the credit costs and information costs are insignificant, implying that spillover effects in the supply chain generate real replacement costs and are not just the result of counterparty risk or of the release of industry information.

\section{Determinants of Customer Spillover Effects}

Panel B of Table 5 presents the results of tests for the cross-sectional determinants of the distress announcement date CARs for our sample of filing firms' customers. Model 1 presents our base model for exploring expected firm replacement costs for individual customers, again using clustered errors. The degree of reliance by the customer on the filing firm and the supplier's level of product specialization (measured by R\&D intensity) are important for downstream contagion, both with negative and significant coefficients ( $t$-statistics of -2.90 and -7.32 , respectively). It appears that the switching costs attributable to product specialization are one of the main drivers of the contagion effects on the customer. Customers who are not reliant on the filing suppliers in terms of their percentage of purchases may still face substantial retooling costs as a result of technological dependence on their suppliers. ${ }^{18}$ The other coefficients are not statistically significant.

Although Panel B of Table 4 suggests that the probability of reorganization is an important determinant of abnormal returns for customers, once we account for the other explanatory variables, the probability of reorganization is not significant, in contrast to its effect on suppliers to distressed firms. A supplier may not have an alternative outlet for its existing goods or services, so losing a key customer may require a substantial effort to replace the distressed partner or even require retooling for a different trading partner. On the other hand, customers of failed firms can presumably pay another firm to deliver similar inputs: the change may raise costs, and those costs are likely to be worse if its supplier is in a concentrated industry and it is purchasing company-specific products. The asymmetric impact on suppliers and customers of losing a trading partner may partially explain the lower announcement effect we observe for customers.

Model 2 of Table 5 looks at information effects alone. In contrast to the suppliers, customers of filing firms do show significant information effects. When we include our information proxy along with the variables that proxy for replace-

\footnotetext{
${ }^{18}$ Ellis, Fee, and Thomas (2012) find that customers reporting significant trading partners (on which our sample is based) tend to be those with lower R\&D expenses. They conjecture that firms with substantial proprietary information may underreport trading partners. Thus, product specialization may be more important than our results suggest.
} 
ment costs (model 3), the replacement cost variables retain their same significance as in model 1 , and the information variable is positive and significant $(t=2.52)$. Therefore, spillover effects in customers of filing firms are not driven solely by replacement costs.

\section{Supplier Performance around Bankruptcy}

In this section, we explore what happens to suppliers following the distress announcement. We focus on two aspects of supplier outcomes and examine whether changes in realized operating performance following bankruptcy appear to be tied to determinants of spillover effects, and we explore whether suppliers appear to adjust their trade-credit policies both leading up to and in Chapter 11 in response to the distress of their trading partners.

\section{A. Realized Supplier Operating Performance}

To calculate performance changes for suppliers, we use a matched firm adjustment approach, following Barber and Lyon (1996) and Fee and Thomas (2004). Each supplier to a filing firm is matched with a control firm chosen on the basis of industry, asset size, and operating performance in the pre-filing year. Starting with the entire universe of Compustat firms, we eliminate all bankrupt firms and their suppliers and customers. From the remaining firms, we identify those in the same 2-digit SIC code with an asset size at the end of the year prior to bankruptcy that is between $25 \%$ and $200 \%$ of the supplier's and an operating profit percentage that is between $90 \%$ and $110 \%$ of the supplier's. From the set of these possible matches, we choose the one closest in operating performance to the supplier. If matches are not found at this stage, the industry screen is relaxed to a 1-digit SIC match requirement. At the next stage, the industry-matching requirement is removed, and matches are made only on the basis of asset size and performance. If we are still left with no match, we use the operating-performance matching only at the last stage. If the matched firm drops out, it is replaced with the next best available match. There is attrition in our sample each year because not all suppliers have more than one match using the most relaxed matching criteria, and not all suppliers have data for all years on Compustat. ${ }^{19}$ We are able to find 200 supplier-matched firm pairs by this process in the year prior to customer bankruptcy. We follow the performance of the sample of suppliers relative to that of their matching firms from the year prior to filing to 3 years after filing. Our aim is to investigate whether supplier pre-filing spillover effects translate into lost sales, increased costs, or overall declining margins.

Table 6 presents several matched-firm-adjusted financial measures for suppliers beginning at time -1 , the fiscal year-end prior to the Chapter 11 filings of their distressed partners. The table also reports year-over-year changes in those measures for the subsequent 4 years. The change in the match-adjusted sales-toassets ratio is negative but insignificant from year 0 (the first fiscal year following the Chapter 11 filing) to year 1 . Changes in the ratio of cost of goods sold to

\footnotetext{
${ }^{19}$ As a check for survivorship bias in our results for this section, we fix all firms that have data in year +3 after the filing (varies from 102 to 83 depending on the particular variable) and redo our tests. Although significance is diminished in these tests, the trends remain the same.
} 


\section{TABLE 6}

\section{Operating Performance of Suppliers Following the Distress Date}

Table 6 presents the match-firm-adjusted measures of operating performance for suppliers to filing firms. Each value is a difference found by subtracting the variable value of the corresponding matching firms. Matching firms are calculated using the Barber and Lyon (1996) method by choosing those matched firms that are closest to each sample supplier firm by industry (2-digit SIC code), size (25\%-200\% of assets), and operating performance (year prior to bankruptcy announcement). The variable changes from year $n-1$ to year $n$ are the difference of each measure between the values in the corresponding years. Year 0 is the fiscal year-end following the bankruptcy filing (see definition of timing convention in Section III). Operating profit is defined as EBITDA. Altman's z-score is from Altman (1968). Panel C presents the regression of match-firm-adjusted operating performance and SG\&A expenses for suppliers to filing firms. The dependent variable is the change in the match-firm-adjusted operating performance or SG\&A of the suppliers from the pre-filing fiscal yearend (year -1) and the fiscal year-end of the following filing year (year 0). Independent variables are described in Table 5. The $p$-values (reported in parentheses in Panels A and B) are calculated from $t$-tests for the means and from Wilcoxon ranked-sum tests for the medians. The $t$-statistics reported in parentheses in Panel $\mathrm{C}$ control for clustering. ${ }^{*}{ }^{* *}$, and ${ }^{* * *}$ indicate significance at the $10 \%, 5 \%$, and $1 \%$ levels, respectively.

Panel A. Match-Firm-Adjusted Revenue, COGS, and Gross Profit Following the Distress Date

\begin{tabular}{|c|c|c|c|c|c|c|c|c|c|}
\hline & \multicolumn{3}{|c|}{ Sales/Assets } & \multicolumn{3}{|c|}{ COGS/Assets } & \multicolumn{3}{|c|}{ Gross Profit/Sales } \\
\hline & No. of Obs. & Mean & Median & No. of Obs. & Mean & Median & No. of Obs. & Mean & Median \\
\hline Value in year -1 & 200 & -0.089 & $0.056^{\star}$ & 200 & -0.085 & $0.031^{\star \star}$ & 200 & -0.004 & 0.000 \\
\hline Change from year -1 to year 0 & 198 & $\begin{array}{c}0.078 \\
(0.53)\end{array}$ & $\begin{array}{c}-0.003 \\
(0.36)\end{array}$ & 198 & $\begin{array}{c}0.095 \\
(0.44)\end{array}$ & $\begin{array}{c}0.003 \\
(0.57)\end{array}$ & 198 & $\begin{array}{c}-0.017 \\
(0.34)\end{array}$ & $\begin{array}{c}-0.004 \\
(0.35)\end{array}$ \\
\hline Change from year 0 to year 1 & 146 & $\begin{array}{c}-0.494 \\
(0.23)\end{array}$ & $\begin{array}{c}-0.012 \\
(0.76)\end{array}$ & $\begin{array}{r}146 \\
(0.27)\end{array}$ & $\begin{array}{c}-0.443 \\
(0.44)\end{array}$ & 0.005 & $\begin{array}{c}122 \\
(0.02)^{\star \star}\end{array}$ & $\begin{array}{c}-0.051 \\
(0.11)\end{array}$ & -0.012 \\
\hline Change from year 1 to year 2 & 130 & $\begin{array}{c}0.742 \\
(0.26)\end{array}$ & $\begin{array}{c}0.024 \\
(0.03)^{\star \star}\end{array}$ & 130 & $\begin{array}{c}0.706 \\
(0.27)\end{array}$ & $\begin{array}{c}0.012 \\
(0.13)\end{array}$ & 130 & $\begin{array}{c}0.035 \\
(0.27)\end{array}$ & $\begin{array}{c}0.013 \\
(0.05)^{\star \star}\end{array}$ \\
\hline Change from year 2 to year 3 & 99 & $\begin{array}{r}0.057 \\
(0.34)\end{array}$ & $\begin{array}{c}0.005 \\
(0.67)\end{array}$ & 99 & $\begin{array}{c}0.057 \\
(0.30)\end{array}$ & $\begin{array}{c}0.008 \\
(0.51)\end{array}$ & 99 & $\begin{array}{c}0.000 \\
(0.99)\end{array}$ & $\begin{array}{c}0.002 \\
(0.53)\end{array}$ \\
\hline
\end{tabular}

Panel B. Match-Firm-Adjusted SG\&A, Operating Profit, and Altman's z-Score Following the Distress Date

\begin{tabular}{|c|c|c|c|c|c|c|c|c|c|}
\hline & \multicolumn{3}{|c|}{ SG\&A/Assets } & \multicolumn{3}{|c|}{ Operating Profit/Assets } & \multicolumn{3}{|c|}{ Altman's z-Score } \\
\hline & No. of Obs. & Mean & Median & No. of Obs. & Mean & Median & No. of Obs. & Mean & Median \\
\hline Value in year -1 & 163 & -0.007 & 0.002 & 200 & 0.000 & 0.000 & 178 & -0.378 & 0.124 \\
\hline Change from year -1 to year 0 & 161 & $\begin{array}{c}0.039 \\
(0.01)^{\star \star \star}\end{array}$ & $\begin{array}{c}0.003 \\
(0.03)^{\star \star}\end{array}$ & 197 & $\begin{array}{c}-0.049 \\
(0.02)^{\star \star}\end{array}$ & $\begin{array}{l}-0.020 \\
(0.01)^{\star \star \star}\end{array}$ & 176 & $\begin{array}{r}-0.017 \\
(0.94)\end{array}$ & $\begin{array}{r}-0.070 \\
(0.09)^{\star}\end{array}$ \\
\hline Change from year 0 to year 1 & 113 & $\begin{array}{c}-0.012 \\
(0.75)\end{array}$ & $\begin{array}{c}0.009 \\
(0.13)\end{array}$ & 145 & $\begin{array}{c}-0.021 \\
(0.41)\end{array}$ & $\begin{array}{c}-0.012 \\
(0.11)\end{array}$ & 129 & $\begin{array}{c}-0.859 \\
(0.04)^{\star \star}\end{array}$ & $\begin{array}{l}-0.130 \\
(0.01)^{\star \star \star}\end{array}$ \\
\hline Change from year 1 to year 2 & 99 & $\begin{array}{c}0.013 \\
(0.36)\end{array}$ & $\begin{array}{c}-0.002 \\
(0.99)\end{array}$ & 127 & $\begin{array}{c}-0.023 \\
(0.54)\end{array}$ & $\begin{array}{c}0.007 \\
(0.26)\end{array}$ & 118 & $\begin{array}{c}0.467 \\
(0.49)\end{array}$ & $\begin{array}{c}0.073 \\
(0.44)\end{array}$ \\
\hline Change from year 2 to year 3 & 77 & $\begin{array}{r}0.027 \\
(0.14)\end{array}$ & $\begin{array}{l}0.003 \\
(0.35)\end{array}$ & 94 & $\begin{array}{r}-0.027 \\
(0.29)\end{array}$ & $\begin{array}{c}0.008 \\
(0.31)\end{array}$ & 87 & $\begin{array}{c}-0.667 \\
(0.04)^{\star \star}\end{array}$ & $\begin{array}{c}-0.009 \\
(0.61)\end{array}$ \\
\hline
\end{tabular}

Panel C. OLS Regressions of Changes in Match-Firm-Adjusted Operating Profit and SG\&A over the Year before Filing to the Year after Emergence

Dependent Variable

\begin{tabular}{|c|c|c|}
\hline Variable & Change in Operating Profit & Change in SG\&A \\
\hline Intercept & $\begin{array}{l}-0.063 \\
(-0.88)\end{array}$ & $\begin{array}{c}0.146 \\
(2.24)^{\star \star}\end{array}$ \\
\hline FILING_CUSTOMER_PROBABILITY_OF_REORGANIZATION & $\begin{array}{c}0.189 \\
(2.11)^{\star \star}\end{array}$ & $\begin{array}{l}-0.187 \\
(-2.56)^{\star \star \star}\end{array}$ \\
\hline \%_SALES_FROM_DISTRESSED_CUSTOMER & $\begin{array}{c}-0.152 \\
(-1.59)\end{array}$ & $\begin{array}{c}0.125 \\
(1.62)\end{array}$ \\
\hline SUPPLIER_R\&D_INTENSITY & $\begin{array}{c}-0.307 \\
(-0.89)\end{array}$ & $\begin{array}{c}0.234 \\
(1.19)\end{array}$ \\
\hline FILING_CUSTOMER_INDUSTRY_CONCENTRATION & $\begin{array}{l}-0.017 \\
(-0.29)\end{array}$ & $\begin{array}{l}-0.117 \\
(-2.60)^{\star \star \star}\end{array}$ \\
\hline SUPPLIER_INDUSTRY_CONCENTRATION & $\begin{array}{c}-0.130 \\
(-2.42)^{\star \star}\end{array}$ & $\begin{array}{l}0.117 \\
(2.46)^{\star \star}\end{array}$ \\
\hline SUPPLIER_LEVERAGE & $\begin{array}{c}0.017 \\
(1.75)^{\star}\end{array}$ & $\begin{array}{c}-0.012 \\
(-1.35)\end{array}$ \\
\hline SUPPLIER_SIZE & $\begin{array}{l}-0.010 \\
(-1.52)\end{array}$ & $\begin{array}{l}-0.001 \\
(-0.20)\end{array}$ \\
\hline $\begin{array}{l}\text { No. of obs. } \\
p \text {-value of } F \text {-statistic } \\
\text { Adj. } R^{2}\end{array}$ & $\begin{array}{l}175 \\
0.0246 \\
0.052\end{array}$ & $\begin{array}{l}\quad 147 \\
0.0019 \\
0.105\end{array}$ \\
\hline
\end{tabular}


assets are insignificant for all years. Gross profits fall significantly at the mean from year 0 to year 1 , and they rise significantly at the median from year 1 to year 2. ${ }^{20}$ Although the results in Panel A are not strongly compelling, they do seem to suggest that suppliers to distressed firms (relative to their matched peers) may have a drop in sales and profits associated with the bankruptcy filings of their distressed partners, followed by a recovery. ${ }^{21}$

The results in Panel B of Table 6 are more interesting. We find that the SG\&A costs of suppliers increase significantly in the filing year, and correspondingly, we observe a significant $2 \%$ median ( $5 \%$ mean) decline in operating profitability relative to a matched sample. Kalwani and Narayandas (1995) find that those suppliers that have long-term relationships with their customers spend less on SG\&A as a result of lower service costs, higher repeat sales, and higher overall effectiveness of selling expenditures rather than simply reflecting a decrease in sales. ${ }^{22}$ Taken together with our earlier results, the evidence suggests that spillover effects attributable to the distress of the filing firm may lead to an erosion of the supplier's combined efficiencies in selling expenses. In addition, if the filing firm liquidates, suppliers have to search for and switch to new customers. We also find evidence of declining financial health of the suppliers from the Altman (1968) $z$-score measure, which declines (marginally significantly for the median) in the year of filing and declines significantly in the year after filing.

In Panel $\mathrm{C}$ of Table 6, we examine determinants of changes in operating profits and SG\&A from time -1 to time 0 using our baseline independent variables. A higher probability of reorganization is positively related to changes in operating profits and negatively related to changes in SG\&A ( $t$-statistic $=2.11,-2.56$, respectively). If the filing customer is in a more concentrated industry, it is likely that it will be more costly for a supplier to find a replacement customer; the coefficient on customer industry concentration is of the expected sign and significant for changes in both operating profits and SG\&A. The SG\&A costs rise less when the supplier is in a concentrated industry.

We examine the changes in operating profits across various subsamples (results not tabulated). We find that when divided according to the degree of reliance, suppliers that generate over $10 \%$ of their sales from the filing customer experience

\footnotetext{
${ }^{20}$ To ascertain whether the results are driven by the denominator of the operating ratios instead of the numerators, we test whether the gross sales and total assets change significantly between year -1 and year 0 . We find that total assets decline, but the decline is not significant. Gross sales remain unchanged on a mean basis, but on a median basis, we find a significant (5\% level) drop in sales. Because the gross profit margin is the only ratio in which we use gross sales as the denominator, we redo this ratio using total assets as the denominator instead of gross sales and find that our results remain qualitatively unchanged.

${ }^{21}$ We repeat the test for changes in sales after deducting the industry median (rather than the matched firm) of the sales-to-assets ratio from that of the supplier firm. Industry is defined at the 4-digit SIC level provided that it contains a minimum of five firms. Otherwise, the industry is defined at the 3-digit or 2-digit SIC level. We find that the median change in sales-to-assets ratio is -4.70 , with a $p$-value of $<0.0001$.

${ }^{22}$ Another possible reason for suppliers' rising SG\&A in the year of filing could be increases in provisions for doubtful debts, which is the current-period expense associated with losses from credit sales and may be included as part of SG\&A expenses. This, in turn, could imply that uncollected accounts receivables may be responsible for the immediate changes in operating performance rather than lost sales or changed production processes.
} 
a significant drop in filing-year operating profit, whereas the drop is insignificant for the nonreliant sample. We also examine whether suppliers operating in a durable goods industry suffer more than those operating in a nondurable goods industry. Banerjee et al. (2008) show that firms operating in durable goods industry make (and need their trading partners to make) more relationship-specific investments because of the nature of the goods in which they transact. Consistent with their results, we find that suppliers operating in a durable goods industry experience larger and more significant drops in operating profit in the year of the filings of their customers.

To summarize, suppliers to bankrupt firms experience substantial negative abnormal returns on the distress announcement effect, and proxies for replacement costs are significant in explaining the cross section of announcement effects. These effects manifest themselves in subsequent changes in operating performance, supporting the hypothesis that deadweight replacement costs are imposed through spillover in the supply chain.

\section{B. Supplier Trade Credit to Distressed Firms}

The incentives of the suppliers to offer credit to a distressed customer may differ from case to case. If the value of the outstanding claim is high enough, the supplier may jeopardize future business with the customer in favor of being paid currently. In other cases, for instance, when a bankrupt customer faces large claims (such as asbestos claims), suppliers may prefer that the customer file for Chapter 11 to ensure that the going-concern value is preserved.

Furthermore, the treatment of trade-credit claims in bankruptcy varies (e.g., some suppliers are granted preferential treatment under a critical vendor motion).

Panel A of Table 7 presents annual univariate measures of match-firmadjusted trade receivables for suppliers (measured as receivables to sales) from year -1 to year 3 . We find that the only year in which there is any significant increase in trade receivables (and only at the 10\% level) is in the fiscal year of filing (year 0 ). This could be the result of suppliers continuing to extend credit to distressed customers but is also consistent with distressed customers repaying receivables late. However, it should be noted that suppliers, especially those that operate on an order-to-order basis, always have the opportunity to change their terms of sale and not to extend trade credit. Prior empirical evidence (e.g., Petersen and Rajan (1997), Molina and Preve (2009), and Shenoy and Williams (2016)) indicates that suppliers extend trade credit to financially constrained customers.

Panel B of Table 7 shows the results of splitting the sample by the type of distress of the filing customer and by reorganization probability groups. At year -1 , the sample firms do not differ significantly from the matched firms. For changes from year -1 to year 0 , only the group of 44 suppliers to financially distressed firms has consistent and significant increases in both the mean and the median trade receivables. This is consistent with the notion that it would be more beneficial for a supplier to extend trade credit to customers that are more likely to remain in business. Similarly, for the probability groups, only the high-reorganizationprobability group has a significant increase in the receivables. One potential criticism of this interpretation is that economically distressed firms may have lower 
demand for credit because their businesses may have declining sales. To understand the mechanics, we turn to the multivariate results in Panel C.

Panel $\mathrm{C}$ of Table 7 presents results from using the change in the matchfirm-adjusted receivables-to-sales ratio from the pre-filing year $(-1)$ to the fiscal year-end after filing (0) as the dependent variable. All the independent variables are measured as the difference between the characteristic of the supplier less its matching-firm characteristic in year -1 . Banerjee et al. (2008) show that firms

\section{TABLE 7}

\section{Match-Firm-Adjusted Trade Receivables of Suppliers to Bankrupt Firms}

Table 7 presents the mean and median year-over-year changes in match-firm-adjusted trade receivables to sales for suppliers to filing firms. Each value is based on a difference found by subtracting the variable value of the corresponding matching firms. The matching for firms is described in Table 6. Year -1 is the fiscal year-end preceding the Chapter 11 filing, year 0 is the fiscal year-end after filing, and so on. Panel B presents the same variable as in Panel $\mathrm{A}$ for subsamples according to the distress type based on the degree-of-distress measure of Lemmon et al. (2009) and estimated reorganization group. See Table 4 for a description of the classification schemes. Panel $\mathrm{C}$ presents the regression of the trade receivables of suppliers. The dependent variable is the change in the ratio of match-firm-adjusted trade receivables to sales of the suppliers in the pre-filing (year -1 ) and the filing year (year 0). Each independent variable except FILING_CUSTOMER_INDUSTRY_CONCENTRATION, SUPPLIER_INDUSTRY_CONCENTRATION, and FILING_CUSTOMER_PROBABILITY_OF_REORGANNIZATION is calculated on a match-firm-adjusted basis. Matched firms are identified using the Barber and Lyon (1996) method by choosing those matched firms that are closest to each sample supplier firm by industry, size, and operating performance (see Table 6 for details). SUPPLIER_ALTMAN_Z_SCORE is from Altman (1968). SUPPLIER_SALES_INTENSITY is measured by sales/total assets. ACCOUNTS_PAYABLE_OF_SUPPLIER is the supplier's trade payables scaled by its COGS. OPERATING_PROFIT_MARGIN_OF_SUPPLIER is defined as the EBITDA/total assets of the supplier. SUPPLIER_SHORT_TERM_DEBT is short-term debt divided by total assets. SUPPLIER_LEVERAGE, SUPPLIER INDUSTRY CONCENTRATION, and FILING CUSTOMER PROBABILITY OF REORGANIZATION are computed as in Table 3. TOBIN'S_Q_OF_SUPPLIER is the market value of assets divided by the book value of assets. The $p$-values reported in parentheses in Panels $A$ and $B$ are calculated from $t$-tests for the means and from Wilcoxon ranked-sum tests for the medians. The $t$-statistics reported in parentheses in Panel $\mathrm{C}$ control for clustering. ${ }^{*},{ }^{\star *}$, and ${ }^{* \star *}$ indicate significance at the $10 \%, 5 \%$, and $1 \%$ levels, respectively.

Panel A. Change in Match-Firm-Adjusted Trade Receivables for Suppliers in the Years around Chapter 11 Filing of Customer

\begin{tabular}{lcrr} 
& \multicolumn{2}{c}{ All Suppliers } & Median \\
\cline { 2 - 4 } & No. of Obs. & Mean & -0.009 \\
\cline { 2 - 4 } Value in year -1 & 187 & -0.062 & -0.001 \\
Change from year -1 to year 0 & 183 & 0.055 & $(0.47)$ \\
& & $(0.06)^{*}$ & -0.004 \\
Change from year 0 to year 1 & 138 & 0.052 & $(0.76)$ \\
Change from year 1 to year 2 & 124 & $(0.47)$ & -0.005 \\
& & -0.060 & $(0.63)$ \\
Change year 2 to year 3 & 92 & $(0.29)$ & -0.005 \\
& & 0.073 & $(0.31)$
\end{tabular}

Panel B. Change in Trade Receivables in the Years around Chapter 11 Filing

Panel B1. Grouped by Distress Type of Filing Customer

\begin{tabular}{|c|c|c|c|c|c|c|c|c|c|}
\hline \multirow[t]{2}{*}{$\begin{array}{c}\text { Trade Receivables/ } \\
\text { Total Assets }\end{array}$} & \multicolumn{3}{|c|}{$\begin{array}{c}\text { Suppliers to } \\
\text { Economically Distressed } \\
\text { Filing Firms }\end{array}$} & \multicolumn{3}{|c|}{$\begin{array}{l}\text { Suppliers to } \\
\text { Mixed Distressed } \\
\text { Filing Firms }\end{array}$} & \multicolumn{3}{|c|}{$\begin{array}{l}\text { Suppliers to } \\
\text { Financially Distressed } \\
\text { Filing Firms }\end{array}$} \\
\hline & No. of Obs. & Mean & Median & No. of Obs. & Mean & Median & No. of Obs. & Mean & Median \\
\hline Value in year -1 & 18 & -0.001 & 0.012 & 118 & -0.066 & -0.009 & 44 & 0.006 & -0.010 \\
\hline Change from year -1 to year 0 & 18 & $\begin{array}{c}0.011 \\
(0.55)\end{array}$ & $\begin{array}{c}0.005 \\
(0.52)\end{array}$ & 118 & $\begin{array}{r}0.000 \\
(0.99)\end{array}$ & $\begin{array}{r}-0.007 \\
(0.20)\end{array}$ & 44 & $\begin{array}{c}0.036 \\
(0.02)^{\star \star}\end{array}$ & $\begin{array}{l}0.025 \\
(0.00)^{\star \star \star *}\end{array}$ \\
\hline
\end{tabular}

Panel B2. Grouped by Reorganization Probability Group of Filing Customer

\begin{tabular}{|c|c|c|c|c|c|c|c|c|c|}
\hline \multirow[t]{2}{*}{$\begin{array}{c}\text { Trade Receivables/ } \\
\text { Total Assets } \\
\end{array}$} & \multicolumn{3}{|c|}{$\begin{array}{l}\text { Suppliers to } \\
\text { Low-Probability } \\
\text { Firms } \\
\end{array}$} & \multicolumn{3}{|c|}{$\begin{array}{c}\text { Suppliers to } \\
\text { Moderate-Probability } \\
\text { Firms }\end{array}$} & \multicolumn{3}{|c|}{$\begin{array}{c}\text { Suppliers to } \\
\text { High-Probability } \\
\text { Firms }\end{array}$} \\
\hline & No. of Obs. & Mean & Median & No. of Obs. & Mean & Median & No. of Obs. & Mean & Median \\
\hline Value in year -1 & 23 & -0.043 & -0.019 & 94 & -0.061 & 0.000 & 63 & -0.014 & -0.020 \\
\hline Change from year -1 to year 0 & 23 & $\begin{array}{c}0.011 \\
(0.68)\end{array}$ & $\begin{array}{c}-0.012 \\
(0.79)\end{array}$ & 94 & $\begin{array}{c}-0.005 \\
(0.84)\end{array}$ & $\begin{array}{c}-0.005 \\
(0.27)\end{array}$ & 63 & $\begin{array}{c}0.032 \\
(0.01)^{\star \star \star}\end{array}$ & $\begin{array}{c}0.014 \\
(0.02)^{\star \star}\end{array}$ \\
\hline
\end{tabular}


TABLE 7 (continued)

Match-Firm-Adjusted Trade Receivables of Suppliers to Bankrupt Firms

Panel C. OLS Regressions of Change in Match-Firm-Adjusted Trade Receivables

\begin{tabular}{|c|c|c|}
\hline \multirow[t]{2}{*}{ Variable } & \multicolumn{2}{|c|}{$\begin{array}{c}\text { Dependent Variable: } \\
\text { Change in Accounts } \\
\text { Receivable/Sales } \\
\text { over the Year before } \\
\text { Filing to the } \\
\text { Year of Filing }\end{array}$} \\
\hline & Model 1 & Model 2 \\
\hline Intercept & $\begin{array}{l}-0.083 \\
(-2.31)^{\star \star}\end{array}$ & $\begin{array}{l}-0.075 \\
(-2.03)^{\star \star}\end{array}$ \\
\hline FILING_CUSTOMER_PROBABILITY_OF_REORGANIZATION & $\begin{array}{l}0.135 \\
(2.80)^{\star \star \star}\end{array}$ & $\begin{array}{l}0.126 \\
(2.57)^{\star \star \star}\end{array}$ \\
\hline ACCOUNTS_PAYABLE_OF_SUPPLIER & $\begin{array}{l}-0.024 \\
(-1.02)\end{array}$ & $\begin{array}{l}-0.024 \\
(-0.91)\end{array}$ \\
\hline OPERATING_PROFIT_MARGIN_OF_SUPPLIER & $\begin{array}{l}2.155 \\
(0.85)\end{array}$ & $\begin{array}{c}2.250 \\
(0.86)\end{array}$ \\
\hline SUPPLIER_SIZE & $\begin{array}{r}0.007 \\
(0.48)\end{array}$ & $\begin{array}{c}0.005 \\
(0.30)\end{array}$ \\
\hline TOBIN'S_Q_OF_SUPPLIER & $\begin{array}{l}-0.004 \\
(-0.91)\end{array}$ & $\begin{array}{l}-0.005 \\
(-1.13)\end{array}$ \\
\hline SUPPLIER_SALES_INTENSITY & $\begin{array}{l}0.021 \\
(2.53)^{\star \star \star \star}\end{array}$ & $\begin{array}{l}0.024 \\
(2.60)^{\star \star \star}\end{array}$ \\
\hline SUPPLIER_LEVERAGE & $\begin{array}{c}-0.018 \\
(-1.92)^{\star}\end{array}$ & $\begin{array}{l}-0.012 \\
(-1.15)\end{array}$ \\
\hline SUPPLIER_INDUSTRY_CONCENTRATION & $\begin{array}{l}-0.120 \\
(-5.25)^{\star \star \star}\end{array}$ & $\begin{array}{l}-0.118 \\
(-5.33)^{\star \star \star}\end{array}$ \\
\hline FILING_CUSTOMER_INDUSTRY_CONCENTRATION & $\begin{array}{c}0.080 \\
(2.12)^{\star \star}\end{array}$ & $\begin{array}{l}0.075 \\
(1.97)^{\star \star}\end{array}$ \\
\hline SUPPLIER_ALTMAN_Z_SCORE & $\begin{array}{l}-0.009 \\
(-2.35)^{\star \star}\end{array}$ & $\begin{array}{c}-0.011 \\
(-2.60)^{\star \star}\end{array}$ \\
\hline SUPPLIER_SHORT_TERM_DEBT & & $\begin{array}{l}-0.056 \\
(-2.47)^{\star \star}\end{array}$ \\
\hline $\begin{array}{l}\text { No. of obs. } \\
p \text {-value of } F \text {-statistic } \\
\text { Adj. } R^{2}\end{array}$ & $\begin{array}{c}136 \\
0.0089 \\
0.1002\end{array}$ & $\begin{array}{c}136 \\
0.0079 \\
0.1070\end{array}$ \\
\hline
\end{tabular}

may attempt to match the maturities of their short-term assets with their shortterm liabilities. Therefore, we include the amount of trade credit used by a firm as a control variable. Other controls included are firm operating profit margin (EBITDA/total assets), firm size (log of total assets), Tobin's $Q$ (market value of assets/book value of assets), sales intensity (sales/total assets), and book leverage (book value of debt/book value of assets). As modeled by Wilner (2000), customers with high market share may be able to exercise higher bargaining power over their dependent suppliers. Therefore, we include Herfindahl indices of both firms as controls in the regression. Finally, we use the supplier's Altman (1968) $z$-score to capture the financial health of the supplier. ${ }^{23}$

We find that the coefficient on the probability of a successful reorganization for the customer is positive and significant, suggesting that to the extent that tradecredit receivables grow around bankruptcy, they do so for suppliers whose filing customers are most likely to emerge from bankruptcy. Results also show that if the financial health of the supplier as measured by Altman's (1968) $z$-score is better, the supplier is likely to record lower increases in trade receivables. Firms

\footnotetext{
${ }^{23}$ We repeat the same regression with Fama-French (1997) industry controls, and the results are stronger with respect to the probability of reorganization. Overall results remain qualitatively the same.
} 
that are in a strong position financially may be able to afford the switching costs of finding a new trading partner. Suppliers operating in more competitive industries and suppliers whose distressed customers operate in more concentrated industries record greater increases in receivables in the year of filing. If the supplier operates in a competitive market, it is more difficult to find new customers. Similarly, if the customer operates in a highly concentrated industry, it is more difficult for the supplier to reroute its sales to a different customer.

Garcia-Appendini and Montoriol-Garriga (2013) and Love, Preve, and Sarria-Allende (2007) examine suppliers' provision of trade credit during periods of tight financing from traditional sources such as banks when trade credit may serve as an alternative to other forms of credit. Both papers investigate whether changes in receivables seem to be demand driven (distressed customers failing to pay their bills) or supply driven (suppliers offering credit to help distressed customers remain afloat). Both papers argue that if suppliers themselves are constrained, they are unable to extend credit. We follow Love et al. (2007) and use the short-term debt-to-assets ratio to capture supplier liquidity. ${ }^{24}$ In model 2 of Panel $\mathrm{C}$ in Table 7, the coefficient on suppliers' short-term debt-to-assets ratio is negative and significant at the $1 \%$ level, suggesting that liquidity constraints may prevent some suppliers from extending as much trade credit as they otherwise would. At least for these trade creditors, some of the changes in trade credit are likely supply driven. Other coefficients in model 2 are similar to those in model 1.

To gain additional insight into suppliers' behavior surrounding trade credit in the period leading up to and during Chapter 11 , we examine the 10 -Ks of our suppliers from the fiscal year-end 3 years before their distressed customers file for Chapter 11 until the fiscal year-end after the bankruptcy is resolved. Unfortunately, much of the discussion in the 10-Ks lacks detail, and in many cases, there is no mention of the treatment of trade credit. Table 8 summarizes our findings in three areas: changes in trade-credit policy preceding the Chapter 11 filing, changes in trade-credit policy during the bankruptcy, and actual or potential losses associated with the bankruptcy.

We are able to find reasonably complete information for 201 suppliers prior to the filings of their distressed partners. Nearly all of the suppliers whose 10-Ks we examine contain standard language about the risks of concentrated sales and receivables with their major customers, but statements about specific changes in credit policies to these customers are rare. Only 15 of the 201 firms report changes to credit policies for their distressed customers prior to the bankruptcy filings: 8 firms reduce credit to their distressed customers, and 7 firms expand credit, 2 in the form of direct financing and 5 by allowing the firms to extend the payment time on receivables. One possible explanation as to why firms omit more explicit discussions is to avoid raising their own financing costs. For example, Genesis Energy LP notes that it was offered less favorable credit following Genesis's revelation that it was exposed to possible losses on its receivables from Enron. Genesis Energy LP's 2001 10-K notes, “In November and December 2001, Genesis experienced an increase in the requests it received to furnish guarantees or letters of credit as a result of the bankruptcy of Enron Corporation ("Enron") and the

\footnotetext{
${ }^{24} \mathrm{We}$ also replace short-term debt with cash. The coefficient is not statistically different from 0 .
} 
TABLE 8

Reported Changes in Trade Credit around Chapter 11

Table 8 contains information from the 10-Ks of major suppliers to firms that filed for Chapter 11. Data are drawn from the $10-K s$ of suppliers beginning 3 fiscal years prior to the Chapter 11 filings of their distressed partners to the fiscal year-end following the resolution of the bankruptcies of the distressed partners. Tightened terms includes reducing the maximum balance permitted for trade credit for the distressed trading partner, shortening payment periods, or requiring prepayment or cash only. Loosened terms or provided funding includes increasing the maximum balance permitted for trade credit, extending payment periods, or providing direct funding, debtor-in-possession funding, or exit funding. Ordinary course or essential vendor includes suppliers that specifically mention that they continue to be paid "in the ordinary course of business" or have received essential vendor status. (Chapter 11 prevents the debtor firm from paying creditors during Chapter 11, but it allows debtor firms to seek permission to pay trade creditors throughout the bankruptcy.) Suppliers often disclose in their financial reports that they face potential losses associated with a trading partner's bankruptcy filing or have experienced actual losses. We split the actual or potential losses into three groups based on the type of loss: accounts receivable only; inventory/property, plant, and equipment (PPE)/joint ventures (JVs)/other only; and firms reporting potential or actual losses in both categories. Suppliers are not consistent in reporting the ultimate resolution of potential losses, so we group references to either an actual or a potential loss together in our counts. No mention indicates that there is no discussion of the relevant aspect of trade credit in the supplier 10-Ks.

\begin{tabular}{lr}
\multicolumn{1}{c}{ Reported Changes } & Number \\
\cline { 2 - 2 } Panel A. Trade-Credit Changes Pre-Filing & \\
\cline { 1 - 2 } Tightened terms & 8 \\
Loosened terms or provided funding & 186 \\
No change or no mention & 201 \\
Total & \\
Panel B. Payment Terms during Chapter 11 & 8 \\
\hline Tightened terms & 2 \\
Loosened terms or provided funding & 20 \\
Ordinary course or essential vendor & 135 \\
No mention of terms & 165 \\
Total & \\
Panel C. Actual or Potential Loss & 25 \\
Accounts receivable only & 9 \\
Inventory/PPE/JVs/other only & \\
Both accounts receivable and & 16 \\
inventory/PPE/JVs/other & 115 \\
No mention of actual or potential loss & 165 \\
Total &
\end{tabular}

Partnership's announcement that it had exposure of \$21 million to an Enron subsidiary. The Partnership received payment in full for its receivable from the Enron subsidiary." Although empirical studies such as that by Shenoy and Williams (2016) conclude that suppliers expand trade credit to financially constrained customers, it appears that changes in credit policies to distressed customers are not highlighted by suppliers in their financial reporting.

Of the suppliers for which we have relatively complete information from 10-Ks after their trading partners' Chapter 11 filings, only about 20\% (30 firms of 165) describe payments following filing (Panel B of Table 8): 8 firms report requiring cash, prepayments, shortened payment times, or reduced credit limits during the bankruptcy; 2 firms supply financing to the bankrupt customer (debtor-in-possession financing in one case and exit financing in another); and 20 firms report being paid "in the ordinary course of business."

Of the 165 firms for which we have 10-Ks, 50 report some sort of actual or potential loss associated with the filings of their partners, including unpaid receivables, inventory write-downs or write-offs, and write-downs or write-offs of partner-specific investments ranging from research programs to property, plant, and equipment (Panel $\mathrm{C}$ of Table 8). The remaining firms either report no significant unpaid claims or are silent on the matter, suggesting that the supplier 
does not have material exposure associated with its partner's bankruptcy. Approximately one-quarter of suppliers (41 firms) report an actual or possible loss on receivables. We also search for any mention of losses arising from partner-specific investments. A total of 25 firms (16 of which also report losses or potential losses on accounts receivable) report potential or actual losses on partner-specific inventory, equipment, or joint ventures.

Although the market lacks complete information on the supplier's exposure at the time of the distress announcement date, if the market's expectation of credit losses is unbiased, we would expect to see a greater reaction for those firms that are more exposed. Firms vary significantly in the detail with which potential losses are reported and are not consistent in reporting recovery rates, so we are unable to obtain consistent estimates of the actual losses borne by suppliers. However, we repeat model 7 in Panel A of Table 5 for those firms for which we have postfiling data and use a dummy variable for those firms that report some sort of loss associated with the filings of their partners. We obtain results very similar to the model reported in the table. The dummy variable has a $t$-statistic of -0.29 , again suggesting that expected credit losses do not explain much of the announcement CAR.

To summarize, suppliers increase their accounts receivable around the announcement of distress for important customers where there is a higher probability that the customer will survive. Suppliers also appear to adjust their accounts receivable in response to the competitive environment, extending additional credit when there are few alternative customers in the industries of their distressed partners or when there is a higher level of competition from other firms in their own industries. However, suppliers may be constrained by a lack of lending capacity. These changes are consistent with suppliers recognizing the potential costs of the failures of their partners and taking action to lower the likelihood of bearing these costs.

\section{Conclusion}

This paper explores whether a firm's distress can transmit costs along the supply chain. We find that, on average, costs of distress flow both upstream and downstream. For both suppliers and customers, the costs of replacing a distressed partner can be significant, indicating that financial distress can impose real costs on other firms. Suppliers whose trading partners are likely to survive bankruptcy appear to face few or no spillover costs. Thus, for suppliers, it is not distress per se that appears to drive the spillover effects but the possibility of losing a partner, in part or in full, and having to incur the cost of replacing that partner. In contrast, part of the impact on customers of distressed firms can be explained by industry-wide information revealed by the trading partner's distress.

Earlier work by Lemmon et al. (2009) suggests that Chapter 11 does a reasonably good job of preserving the assets, reducing the leverage, and promoting the survival of firms that are purely financially distressed. We find that Chapter 11's efficacy in reorganizing financially distressed firms extends to their suppliers: bankrupt firms that are highly likely to emerge from Chapter 11 with little change in scale also transmit few or no costs to their suppliers. In addition, our empirical 
results suggest that trade-credit losses have only a modest effect on the negative returns to suppliers, and suppliers' financial statements indicate that many suppliers appear to be paid "in the ordinary course of business" during the bankruptcies of their distressed partners. This is in sharp contrast to other types of creditors whose ability to collect on their debts is stayed during bankruptcy. Suppliers to economically distressed firms, however, experience substantial losses, which are tied to the costs of replacing their distressed partners. The announcement-period abnormal return is explained both by the likelihood the partner will survive and by proxies for the cost of replacing the partner, including the strength of the relationship, product specificity, and industry concentration. We track suppliers following their partners' bankruptcy filings and observe reduced profit margins and increased SG\&A costs, suggesting that losing a major trading partner leads to real switching costs for trading partners, particularly for firms with partner-specific relationships. Suppliers to firms with reorganization probabilities below $40 \%$ lose an average of $19 \%$ of their market cap at our announcement date. Thus, Chapter 11 's emphasis on avoiding the social cost of suboptimally liquidating firms with going-concern value also avoids forcing suppliers to incur the cost of replacing a viable trading partner.

\section{References}

Acharya, V.; S. Bharath; and A. Srinivasan. "Does Industry-Wide Distress Affect Defaulted Firms? Evidence from Creditor Recoveries.” Journal of Financial Economics, 85 (2007), 787-821.

Aghion, P.; O. Hart; and J. Moore. "The Economics of Bankruptcy Reform." Journal of Law, Economics, and Organization, 8 (1992), 523-546.

Allen, J., and G. M. Phillips. "Corporate Equity Ownership, Strategic Alliances and Product Market Relationships.” Journal of Finance, 55 (2000), 2791-2815.

Altman, E. I. "Financial Ratios, Discriminant Analysis, and the Prediction of Corporate Bankruptcy." Journal of Finance, 23 (1968), 589-609.

Asquith, P.; R. Gertner; and D. Scharfstein. "Anatomy of Financial Distress: An Examination of JunkBond Issuers.” Quarterly Journal of Economics, 109 (1994), 625-658.

Banerjee, S.; S. Dasgupta; and Y. Kim. "Buyer-Supplier Relationships and the Stakeholder Theory of Capital Structure.” Journal of Finance, 63 (2008), 2505-2557.

Barber, B. M., and J. Lyon. "Detecting Abnormal Operating Performance: The Empirical Power and Specification of Test Statistics." Journal of Financial Economics, 41 (1996), 359-399.

Biais, B., and C. Gollier. "Trade Credit and Credit Rationing." Review of Financial Studies, 10 (1997), 903-937.

Boone, A., and V. Ivanov. "Bankruptcy Spillover Effects on Strategic Alliance Partners." Journal of Financial Economics, 103 (2012), 551-569.

Bowen, R.; L. DuCharme; and D. Shores. "Stakeholders' Implicit Claims and Accounting Method Choice." Journal of Accounting and Economics, 20 (1995), 255-295.

Brennan, M.; V. Maksimovic; and J. Zechner. "Vendor Financing." Journal of Finance, 43 (1988), 1127-1141.

Brown, S., and J. Warner. "Using Daily Stock Returns: The Case of Event Studies.” Journal of Financial Economics, 14 (1985), 3-31.

Burkart, M., and T. Ellingsen. "In-Kind Finance: A Theory of Trade Credit." American Economic Review, 94 (2004), 569-590.

Ellis, J.; C. Fee; and S. Thomas. "Proprietary Costs and the Disclosure of Information about Customers." Journal of Accounting Research, 50 (2012), 685-727.

Fama, E., and K. French. "Industry Costs of Equity." Journal of Financial Economics, 43 (1997), $153-193$.

Fee, C.; C. Hadlock; and S. Thomas. "Corporate Equity Ownership and the Governance of Product Market Relationship.” Journal of Finance, 61 (2006), 1217-1251.

Fee, C., and S. Thomas. "Sources of Gains in Horizontal Mergers: Evidence from Customer, Supplier, and Rival Firms.” Journal of Financial Economics, 74 (2004), 423-460. 
Ferris, S.; N. N. Jayaraman; and A. Makhija. "The Response of Competitors to Announcements of Bankruptcy: An Empirical Examination of Contagion and Competitive Effects." Journal of Corporate Finance, 3 (1997), 367-395.

Franks, J., and W. Torous. "A Comparison of Financial Recontracting in Distressed Exchanges and Chapter 11 Reorganizations.” Journal of Financial Economics, 35 (1994), 349-370.

Garcia-Appendini, E., and J. Montoriol-Garriga. "Firms as Liquidity Providers: Evidence from the 2007-2008 Financial Crisis.” Journal of Financial Economic, 109 (2013), 272-291.

Gilson, S. C.; K. John; and L. Lang. "Troubled Debt Restructurings: An Empirical Study of Private Reorganization of Firms in Default." Journal of Financial Economics, 27 (1990), 315-353.

Helwege, J., and G. Zhang. "Financial Firm Bankruptcy and Contagion." Review of Finance, 20 (2016), 1321-1362.

Hertzel, M.; Z. Li; M. Officer; and K. Rogers. "Inter-Firm Linkages and the Wealth Effects of Financial Distress along the Supply Chain.” Journal of Financial Economics, 87 (2008), 374-387.

Holmstrom, B., and J. Roberts. "The Boundaries of the Firm Revisited." Journal of Economic Perspectives, 12 (1998), 73-94.

Jorion, P., and G. Zhang. "Good and Bad Credit Contagion: Evidence from Credit Default Swaps." Journal of Financial Economics, 84 (2007), 860-883.

Jorion, P., and G. Zhang. "Credit Contagion from Counterparty Risk.” Journal of Finance, 64 (2009), 2053-2087.

Kale, J., and H. Shahrur. "Corporate Capital Structure and the Characteristics of Suppliers and Customers." Journal of Financial Economics, 83 (2007), 321-365.

Kalwani, M., and N. Narayandas. "Long-Term Manufacturer-Supplier Relationships: Do They Pay Off for Supplier Firms?” Journal of Marketing, 59 (1995), 1-16.

Lang, L., and R. Stulz. "Contagion and Competitive Intra-Industry Effects of Bankruptcy Announcements.” Journal of Financial Economics, 32 (1992), 45-60.

Lemmon, M.; Y. Ma; and E. Tashjian. "Survival of the Fittest? Financial and Economic Distress and Restructuring Outcomes in Chapter 11.” Working Paper, University of Utah (2009).

Levy, D. "The Transactions Cost Approach to Vertical Integration: An Empirical Examination." Review of Economics and Statistics, 67 (1985), 438-445.

Love, I.; L. Preve; and V. Sarria-Allende. "Trade Credit and Bank Credit: Evidence from Recent Financial Crises." Journal of Financial Economics, 83 (2007), 453-469.

Molina, C., and L. Preve. "Trade Receivables Policy of Distressed Firms and Its Effect on the Costs of Financial Distress." Financial Management, 38 (2009), 663-686.

Opler, T., and S. Titman. "Financial Distress and Corporate Performance." Journal of Finance, 49 (1994), 1015-1040.

Patell, J. "Corporate Forecasts of Earnings per Share and Stock Price Behavior: Empirical Test.” Journal of Accounting Research, 14 (1976), 246-276.

Petersen, M., and R. Rajan. "Trade Credit: Theories and Evidence." Review of Financial Studies, 10 (1997), 661-691.

Raman, K., and H. Shahrur. "Relationship-Specific Investments and Earnings Management: Evidence on Corporate Suppliers and Customers." Accounting Review, 83 (2008), 1041-1081.

Shenoy, J., and R. Williams. "Trade Credit and the Joint Effects of Supplier and Customer Financial Characteristics." Journal of Financial Intermediation, (2016), forthcoming.

Smith, J. "Trade Credit and Information Asymmetry." Journal of Finance, 42 (1987), 863-872.

Tashjian, E.; R. Lease; and J. McConnell. "Prepacks: An Empirical Analysis of Prepackaged Bankruptcies.” Journal of Financial Economics, 40 (1996), 135-162.

Titman, S. "The Effect of Capital Structure on a Firm's Liquidation Decision." Journal of Financial Economics, 13 (1984), 137-151.

Titman, S., and R. Wessels. "The Determinants of Capital Structure Choice.” Journal of Finance, 43 (1988), 1-19.

Weiss, L., and K. Wruck. "Information Problems, Conflicts of Interest, and Asset Stripping: Chapter 11's Failure in the Case of Eastern Airlines." Journal of Financial Economics, 48 (1998), 55-97.

Wilner, B. "The Exploitation of Relationships in Financial Distress: The Case of Trade Credit." Journal of Finance, 55 (2000), 153-178. 